\title{
Antimetastatic Effects of Curcumin in Oral and Gastrointestinal Cancers
}

\section{OPEN ACCESS}

Edited by:

Ramin Massoumi,

Lund University, Sweden

Reviewed by:

Cedric Coulouarn,

INSERM U1242 Laboratoire COSS,

France

Yashodhar Bhandary,

India

*Correspondence:

Ghazaleh Baniebrahimi Ghazalebaniebrahimi@gmail.com Hamed Mirzaei

h.mirzaei2002@gmail.com

Specialty section:

This article was submitted to Gastrointestinal and Hepatic Pharmacology,

a section of the journal

Frontiers in Pharmacology

Received: 16 February 2021

Accepted: 05 July 2021

Published: 11 August 2021

Citation:

Davoodvandi A, Farshadi M, Zare N, Akhlagh SA, Alipour Nosrani E, Mahjoubin-Tehran M, Kangari $P$,

Sharafi SM, Khan H, Aschner M, Baniebrahimi $G$ and Mirzaei $H$ (2021) Antimetastatic Effects of Curcumin in

Oral and Gastrointestinal Cancers.

Front. Pharmacol. 12:668567.

doi: 10.3389/fphar.2021.668567

\author{
Amirhossein Davoodvandi ${ }^{1,2}$, Marjan Farshadi ${ }^{3}$, Noushid Zare ${ }^{4}$, Seyed Amirreza Akhlagh ${ }^{5}$, \\ Esmail Alipour Nosrani ${ }^{6}$, Maryam Mahjoubin-Tehran ${ }^{7}$, Parisa Kangari ${ }^{8}$, \\ Seyedeh Maryam Sharafi ${ }^{9}$, Haroon Khan ${ }^{10}$, Michael Aschner ${ }^{11}$, Ghazaleh Baniebrahimi ${ }^{12 *}$ \\ and Hamed Mirzaei ${ }^{13 *}$
}

${ }^{1}$ Student Research Committee, Kashan University of Medical Sciences, Kashan, Iran, ${ }^{2}$ Cancer Immunology Project (CIP), Universal Scientific Education and Research Network (USERN), Tehran, Iran, ${ }^{3}$ Giamed Corp., Richmond Hill, ON, Canada, ${ }^{4}$ Faculty of Pharmacy, International Campus, Tehran University of Medical Science, Tehran, Iran, ${ }^{5}$ School of Medicine, Shiraz University of Medical Sciences, Shiraz, Iran, ${ }^{6}$ Department of Nutrition, Science and Research Branch, Islamic Azad University, Tehran, Iran, 'Department of Medical Biotechnology, Faculty of Medicine, Mashhad University of Medical Sciences, Mashhad, Iran, ${ }^{8}$ Department of Tissue Engineering and Applied Cell Sciences, School of Advanced Medical Sciences and Technologies, Shiraz University of Medical Sciences, Shiraz, Iran, ${ }^{9}$ Environment Research Center, Research Institute for Primordial Prevention of Non-Communicable Disease, Isfahan University of Medical Sciences, Isfahan, Iran, ${ }^{10}$ Department of Pharmacy, Abdul Wali Khan University, Mardan, Pakistan, ${ }^{11}$ Department of Molecular Pharmacology, Albert Einstein College of Medicine, Bronx, NY, United States, ${ }^{12}$ Department of Pediatric Dentistry, School of Dentistry, Tehran University of Medical Sciences, Tehran, Iran, ${ }^{13}$ Research Center for Biochemistry and Nutrition in Metabolic Diseases, Institute for Basic Sciences, Kashan University of Medical Sciences, Kashan, Iran

Gastrointestinal (Gl) cancers are known as frequently occurred solid malignant tumors that can cause the high rate mortality in the world. Metastasis is a significant destructive feature of tumoral cells, which directly correlates with decreased prognosis and survival. Curcumin, which is found in turmeric, has been identified as a potent therapeutic natural bioactive compound (Curcuma longa). It has been traditionally applied for centuries to treat different diseases, and it has shown efficacy for its anticancer properties. Numerous studies have revealed that curcumin inhibits migration and metastasis of $\mathrm{Gl}$ cancer cells by modulating various genes and proteins, i.e., growth factors, inflammatory cytokines and their receptors, different types of enzymes, caspases, cell adhesion molecules, and cell cycle proteins. Herein, we summarized the antimetastatic effects of curcumin in Gl cancers, including pancreatic cancer, gastric cancer, colorectal cancer, oral cancer, and esophageal cancer.

Keywords: gastrointestinal cancer (GI cancer), curcumin, therapy, metastasis, gastric cancer

\section{INTRODUCTION}

Various mechanisms are involved in the induction of malignant neoplasms in the gastrointestinal tract (Sharma and Bhatia, 2018). Most of the upper gastrointestinal tract carcinomas are caused by aggregated genetic events and uninterrupted mucosal injury (Sharma and Bhatia, 2018). While preexisting adenomas are the origin of colorectal carcinomas, typically. Chronic injuries resulted in prolonged-mucosal damages such as inflammatory bowel disease (IBD). It causes a small number of cancers in the lower parts of the gastrointestinal tract (Axelrad et al., 2016). Research on the molecular pathways has led to considerable advances in the understanding of tumor progression processes. For example, detecting different mutations that affect tumor suppressor genes or those involved in DNA repair may be applicable for identifying the patients with heritable cancer risk (Wang et al., 2018). Besides, others show therapeutic indications. A growing number of oncogenic 
mutations have been recognized in gastrointestinal malignancies, which may be applied or manipulated (Lv, 2017).

Metastasis is disseminating tumoral cells from the original tumor to the primary organ's potential locations or other contiguous and remote organs (Das et al., 2020). As the significant destructive feature of tumoral cells, the incidence of metastasis in various types of cancer directly correlates with decreased prognosis and survival in patients (Deepak et al., 2020). Malignant cells dissemination of primary tumor is the first step for metastasis initiation, intravasation into the blood circulation system is considered the next step, the third step is linked to arrest of tumoral cells in a distant vascular bed, and in the fourth step, cancer cells extravasation into the interstitial tissue of a target organ occurs (Fouani et al., 2017). During the metastasis process and proliferation in a metastatic site, revascularization plays a crucial role in malignant spread, as it supplies the metabolic requirements for the fast duplicating malignant cells (Bielenberg and Zetter, 2015; Luo et al., 2020).

Curcumin or [(1E,6E)-1,7-bis(4-hydroxy-3-methoxyphenyl)1,6-heptadiene-3,5-dione] is a polyphenolic extraction of Curcuma longa species, which is often termed as turmeric (Shafabakhsh et al., 2019; Ashrafizadeh et al., 2020). Curcumin had been used as a traditional Ayurvedic medicine due to its significant anti-inflammatory (Satoskar et al., 1986), antioxidant (Masuda et al., 2001), and antimicrobial (Negi et al., 1999) properties. Currently, curcumin is associated with powerful anticancer properties. Different animal studies have shown that curcumin has important roles in inhibiting primary tumorigenesis in numerous organs as metastatic sites, such as mammary glands (Inano et al., 1999) and gastrointestinal tract (Huang et al., 1994). Some investigations showed that curcumin has potential regulatory effects on the expression of proangiogenic growth factors (6-8). Curcumin inhibits angiogenic activities caused by fibroblast growth factor (bFGF) in rabbit and mouse models (Mohan et al., 2000). It also diminished the vascular endothelial growth factor (VEGF) serum levels in mice models of hepatocellular carcinoma (Yoysungnoen et al., 2006). Interleukin (IL)-1 $\beta$ and monocyte chemotactic protein-1 (MCP-1) are critical inflammatory cytokines in tumorigenesis. Accordingly, some studies demonstrated that these cytokines' expression levels reduced after curcumin intervention (Abe et al., 1999).

The dynamic interplay between neoplastic cells and the immune microenvironment regulates multiple steps in the metastatic process. The tumor-specific immunosuppressive microenvironment serves an important function in tumor tolerance and escapes from immune surveillance leading to tumor progression. Therefore, identifying new drugs or foods that can enhance the tumor immune response is critical to develop improved cancer prevention methods and treatment. Recent studies have also indicated that curcumin can modulate tumor immune responses and remodel the tumor immunosuppressive microenvironment, indicating its potential in the immunotherapy of cancer (Mukherjee et al., 2018; Bahrami et al., 2019a; Pan et al., 2019). Curcumin has antimetastatic activities, modulating $\mathrm{T}$ cells, $\mathrm{B}$ cells, macrophages, neutrophils, NK cells, dendritic cells and production of cytokines and chemokines. In addition, recent studies have shown that curcumin exerts immunosuppressive effects (Shafabakhsh et al., 2019).

These findings showed that curcumin has crucial roles in the inhibition of angiogenesis and metastasis in GI cancers. Also, both the important events, including angiogenesis and inflammation, have been shown to contribute to metastatic formation and proliferation in GI cancers. Herein, we have summarized antimetastatic effects of curcumin in GI cancers.

\section{METASTASIS}

"Metastasis" is an important process in which secondary tumors are developed in one of the organs that are separate from the original primary cancer site. Considering its considerable functions in the induction of failures in cancer management and increasing rate of mortality, apoptosis has been poorly understood currently. Although in vivo studies suggested that the percentage of metastases in melanoma cancer patients is $<0.1 \%$ of tumor cells, but a more significant number of cancerous cells are released in blood circulation in other types of cancer (Luzzi et al., 1998). To metastases progression, tumoral cells must move from their primary tumor site, disperse in blood circulation, tolerate blood vessels' pressure, conform to new cellular settings in a secondary tumor location, and avoid immunological responses (Maitra, 2019; Massagué and Obenauf, 2016). Hanahan and Weinberg (2011) have declared that "invasion and metastasis activation" are signs of tumors. Therefore, metastasis as a major characteristic of cancer malignancies, accession to power from presentation of invasiveness features in surrounding tissue and homing on distant sites. Several factors such as tumor-secreted factors and exosomes dictate metastatic development (Figure 1). Unfortunately, metastasis represents the primary cause of death in a percentage of $>90 \%$ of cancer patients (Steeg, 2006). Herein, comprehending connections of metastatic processes help us to recognize molecular and cellular targets for designing optimal therapies for suppressing or attenuating metastasis and consequent cancer progression. As mentioned earlier, cancer cell dissemination is the initial step of the metastases processes (Lambert et al., 2017). Chromosome segregation continuous errors during mitosis can lead to chromosomal instability, which is the potential cause in the induction of metastasis cascade (Figure 2). Numerous molecular and cellular factors have roles in invasion and metastasis activation, such as epigenetic factors, adhesive signals of extracellular matrix (ECM) components, ECM mechanical pressures, cell-cell interactions, soluble signals, and the intratumoral microbiota. Rupture of micronuclei via chromosome segregation errors leads to genomic DNA secretion into the cytosol. It functions as a cytosolic DNAsensing pathways activator (cyclic GMP-AMP synthase-stimulator of interferon (IFN) genes) and finally activation of nuclear factor ?-light-chain-enhancer B (NF- $\kappa \mathrm{B})$ signaling pathway (Bakhoum et al., 2018).

Various studies have suggested that the primary disseminate nature of tumoral cells can be used as a potent determinant 

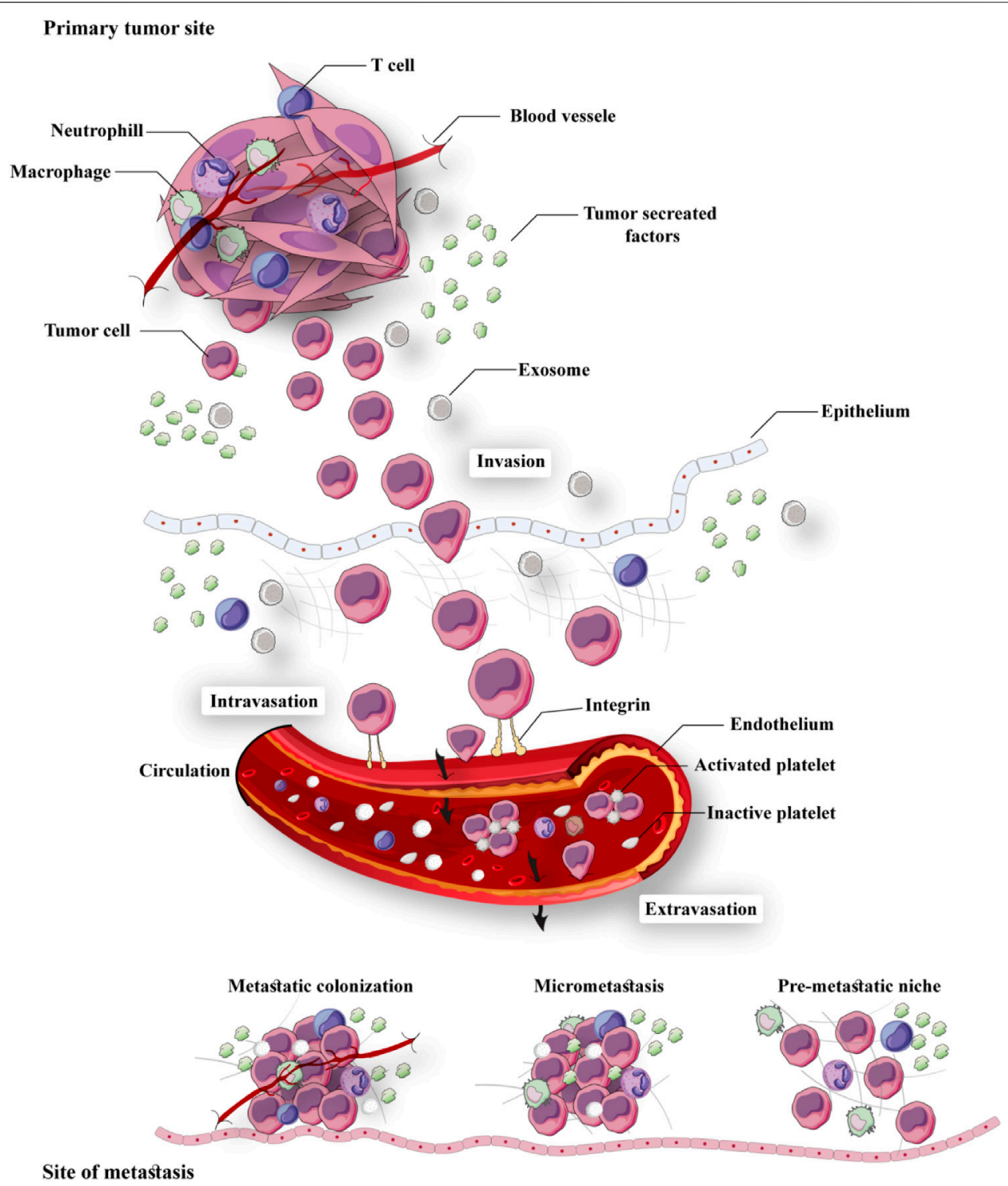

FIGURE 1 | Summary of the metastatic cascade: The metastatic cascade is subdivided into multiple main steps, including invasion, intravasation, circulation, extravasation, and colonization.

(Tabassum and Polyak, 2015; Gundem et al., 2015). An individual migration pattern of metastatic cancer cells was observed in vivo and in vitro investigations (Clark and Vignjevic, 2015). Inversely, in human cancer patients, the concerted action of a cluster of tumor cells is required for seeding (Cheung and Ewald, 2016). The ability of invasiveness, resistant stress, and dissemination of transformed epithelial cells develop in a trans-differentiation process called epithelial-mesenchymal transition (EMT) (Hanahan and Weinberg, 2011). Immotility and tight bounding together are some of the key features of epithelial cells. Also, epithelial cells are closely allied to the neighboring extracellular matrix (ECM) (Fouad and Aanei, 2017). Through governing reversible biochemical alterations, EMT accounts for permitting a specific epithelial cell for achieving a mesenchymal phenotype that admits significant epithelial-mesenchymal plasticity (Ye and Weinberg, 2015). Epithelial-mesenchymal plasticity is an essential specification for the development and metastasis of cancer cells (Figure 3). There are two main invasion patterns of tumor cells: single-cell dissemination and collectivecell migration. Current understanding of metastatic cell migration has relied primarily on studies on single-cell migration. However, the current paradigm focused on singlecell movements is shifting toward a dogma that collective migration is likely one of the primary modes of migration during metastasis of many solid tumors. Not surprisingly, the mechanics of collective migration differ significantly from singlecell movements (Lintz et al., 2017).

Moreover, it has been proved that all of the tumoral cells which originated from the primary site of the tumor have not to function in the contribution of metastasis development. It has been 


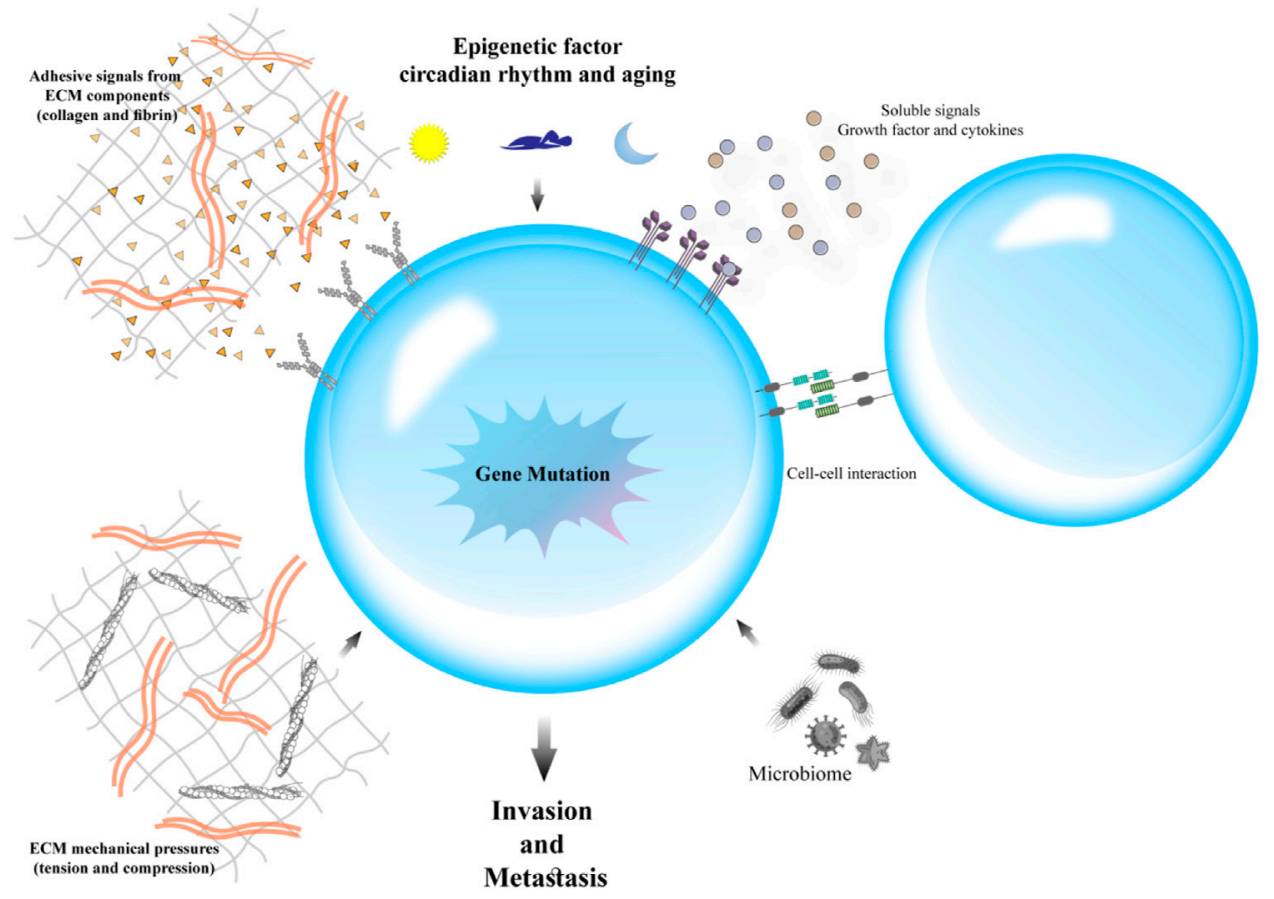

FIGURE 2 | Factors involved in cancer metastasis: Several molecular and cellular factors contribute to invasion and metastasis activation, including epigenetic factors, adhesive signals of extracellular matrix (ECM) components, ECM mechanical pressures, cell-cell interactions, soluble signals, and the intratumoral microbiota.

reported that an increased level of asparagine synthetase, which acts as a pivotal metabolic enzyme, is associated with metastasis progression in mouse-bearing breast cancer (Knott et al., 2018). Treatment with L-asparaginase or dietary restriction-mediated decreasing in the level of asparagine has been reported to be an optimal strategy for reducing metastatic spread. Furthermore, recent studies have demonstrated that the availability of asparagine could lead to promoted EMT (Knott et al., 2018). Recently, a pseudo choice between full-mesenchymal phenotypes or full-epithelial in the EMT process has been rejected. At the same time, we have understood that EMT is a program with various transitional stages between the mesenchymal and epithelial phenotypes (Nieto et al., 2016). Various growth factors (Katsuno et al., 2013) and signaling cascades are governing the transition of the stage to each other in the EMT program (Craene and Berx, 2013). To that end, spontaneous EMT is shifting between various intermediate stages and intermediate phenotypes with extended invasive, metastatic, and differentiation features in primary tumor cells (Pastushenko et al., 2018). For observing better effectiveness in circulation and colonization at the secondary site and the consequent progression of metastases, tumor cells must have a combination of mesenchymal and epithelial phenotypes in EMT (Pastushenko et al., 2018). Numerous distinct and common transcriptional factors and signaling pathways regulate different cellular characteristics, chromatin landscapes, and gene expression signatures in various EMT stages (Pastushenko et al., 2018).

\section{METASTASIS INDUCTION}

\section{Metastasis and Matrix Metalloproteinases}

Degrading of basal membrane and extracellular matrix, which is caused by proteolytic agents such as matrix metalloproteinases (MMPs), can lead to peritumoral matrix destruction and subsequent invasive growth pattern (Brooks et al., 2010). To that end, MMP plays a crucial role in the invasion and metastases through entering the lymphatic system and blood circulation and then increasing the dissemination of tumor cells from the primary tumors into the enclosing tissues and secondary tumor sites.

In various in vivo and in vitro experimental studies, the upregulated expression level of MMPs has been correlated with significant growth and proliferation behavior of tumoral cells (Bachmeier et al., 2000a; Bachmeier et al., 2000b; Bachmeier et al., 2001; Murphy and Nagase, 2008). MMPs play pivotal functions in various tumor development features via affecting numerous biological processes. These features include activation of growth factor (Egeblad and Werb, 2002), tumor growth, induction of invasiveness, tumor-related inflammation, revascularization, and metastasis (Han et al., 2001; Philip et al., 2001). Hence, controlling expression levels of MMPs and suppression of its activation can be considered an optimal strategy for the prevention of cancer development.

Gene transcription is the first level that MMP expression inhibition initiates at that level. The promoter regions contribute to encoding the MMP-1, $-2,-3,-7,-9,-12$, and -13 genes, which are similar to NF- $\mathrm{kB}$ elements, carry a proximal 


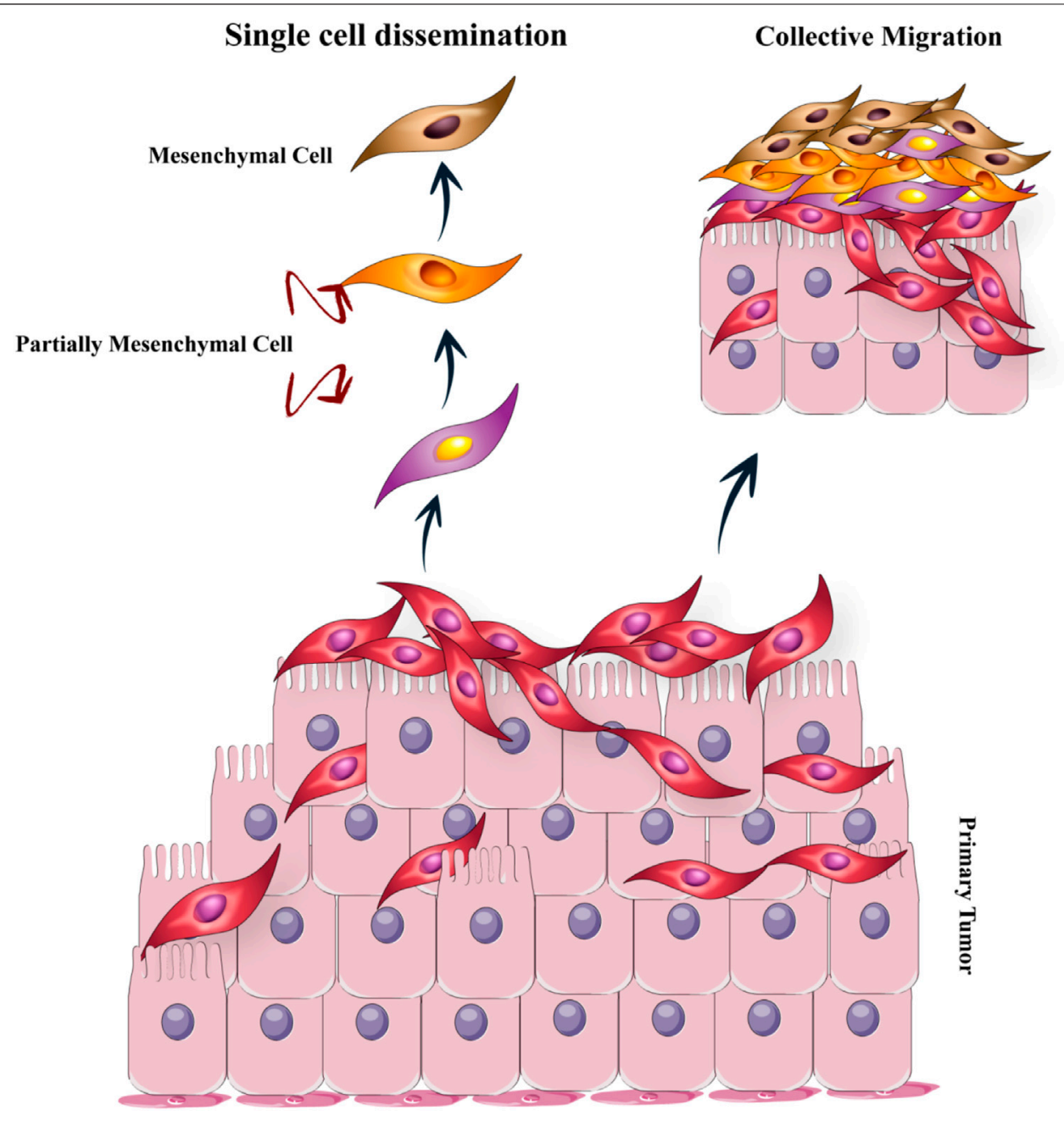

FIGURE 3 The epithelial-mesenchymal transition (EMT): The EMT program is a cell state that epithelial cells acquire mesenchymal cell properties and are capable of migration. There are two main invasion patterns of tumor cells: individual cell dissemination and collective cell migration.

activating-protein-1 (AP-1) binding site about 70 base pair $5^{\prime}$ for starting the transcription (Vincenti et al., 1998; Westermarck and Kähäri, 1999; Bond et al., 2001; Vincenti, 2001).

The properties of curcumin on the expression level of MMP and its functions have been investigated in different experimental studies in various kinds of inflammatory diseases and cancer models (Lin et al., 1998; Banerji et al., 2004; Swarnakar et al., 2005; Hong et al., 2006; Mitra et al., 2006; Su et al., 2006; Bachmeier et al., 2007; Shakibaei et al., 2007). By downregulating the expression of AP-1 and NF- $\kappa$, curcumin has been demonstrated to be a significant suppressor of MMPs synthesis (Bachmeier et al., 2007). Kim et al. reported that, through suppressing the activation of NF- $\kappa \mathrm{B}$ and AP-1, curcumin inhibited the expression of MMP-9 and accompanied cell invasion mediated by12-Otetradecanoylphorbol-13-acetate treatment (Kim et al., 2012a).

Bachmeier and colleagues demonstrated that the MMP-1 and MMP-2 mRNA expression and protein levels were considerably diminished after treatment with curcumin in breast cancer cells.
In contrast, there was no considerable decrease in the expression levels of MMP-3 and -9 (Bachmeier et al., 2007). Furthermore, gelatinolytic activity has been evaluated by zymography, revealed that gelatinases MMP-2 and -9 proteolytic activities, downregulated after treatment with curcumin.

An in vitro investigation on human fibrosarcoma cells demonstrated that the MMP-2 and MMP-9 expression levels were remarkably suppressed after treatment with three separate curcuminoids (demethoxycurcumin, bisdemethoxycurcumin, and curcumin). In comparison, there were no remarkable properties of the invasiveness of these cells and the urokinase plasmin activator (uPA) (Yodkeeree et al., 2008). To that end, in laryngeal squamous carcinoma cells, curcumin treatment induced significant down-regulatory impacts on the MMP-2, MT1-MMP expression, integrin receptors, and focal adhesion kinase (FAK), which led to a remarkable reduction in the invasiveness features of the tumoral cells. It is essential to state that the expression levels of MT1-MMP, MMP-2, integrin receptors, and FAK were similar to regulated expression levels 
after drug withdrawal (Mitra et al., 2006). Treatment with curcumin in human colon cancer cells caused a significant up and downregulation of MMP-9 and MMP-2, respectively. But any remarkable effect on the MMP-7 expression has not been observed, as evidenced by protein levels in Western blotting assay (Su et al., 2006). Curcumin treatment caused a noteworthy reduction in MMP-2 and MMP-9 expression, in conjunction with reduced cellular invasion in vitro in prostate cancer cells (DU-145). Besides, curcumin treatment diminished tumorigenicity in a xenograft model (Hong et al., 2006). Fifteen days of intervention with curcumin in a metastatic model of murine melanoma cells B16F10 remarkably decreased MMP-2 activity (Banerji et al., 2004). Besides, curcumin also reduced FAK and MT1-MMP expression. Results showed that even following 28 days, drug withdrawal could not return the MMP-2, MT1-MMP, and FAK expression to control levels. In the same study, curcumin caused a significant reduction in the level of invasiveness and migration and, reversely, promoted apoptosis in vitro (Philip and Kundu, 2003; Philip et al., 2004). In glioma cell lines, curcumin suppressed the TPA-mediated expression level of MMP-1, -3, -9, and -14-related mRNAs (Woo et al., 2005). On the other hand, following the curcumin intervention, the expression of numerous cell survival and proliferative inducer agents, such as cyclin D1, COX-2, IL-6, MMP-9, and Bcl-2, were significantly suppressed in the squamous carcinoma cells of the head and neck (Aggarwal et al., 2004). Following the curcumin treatment in a xenograft model of prostatic cancer, MMP-9 and MMP-2 expression remarkably decreased. Furthermore, a remarkable inhibitory effect on the invasion ability of the tumoral cells was observed in vitro. In this study, tumor volume, several metastatic nodules in the animal model, and the MP-2 and MMP-9 activity in the tumor-bearing site reduced significantly (Hong et al., 2006). Along with inhibition of ER downstream pS2 and TGF $\beta$ target genes, curcumin treatment in MCF-7 cell lines of breast cancer and estrogen presence significantly suppressed the estrogen receptor (ER) expression. By this study, curcumin treatment also showed significant down-regulatory effects on MMP-2 expression, while TIMP-1 (tissue inhibitor of metalloproteinase) expression was markedly upregulated after curcumin treatment (Shao et al., 2002).

Besides, different studies also have evaluated the properties of curcumin on the invasiveness of lung cancer models: through suppression of MMP-2, -9, and VEGF expression, curcumin significantly decreased migration features and invasiveness of A549 cell line in a time-dose-dependent manner (Lin et al., 2009). The above-mentioned effects were also observed in an in vivo model by affecting the expression of the $801 \mathrm{D}$ cell. Inhibition of the Rac-dependent pathway by curcumin caused a remarkable decrease in the MMP-2 and -9 expression levels (Chen et al., 2014).

Overall, considering slight differences in the efficiency of curcumin in the inhibition of MMPs in some cell lines or studies, it seems that curcumin has significant modulatory effects in virtually all of MMPs. These minor discrepancies may result from slight differences in curcumin-related responsivity and partial resistance of some cell lines
(Bachmeier et al., 2009). Furthermore, it is evident that curcumin considerably plays pivotal functions in inhibiting degradation in some of the extracellular matrix and basal membrane components. These effects are due to its potential action in regulating MMP/TIMP activity and expression, which was led to the significant impacts on the reversion of tumor invasion and growth.

\section{Metastasis and RAF/MEK/RAS/ERK Signaling Pathway}

The RAF/MEK/RAS/ERK signaling pathway is the primary modulator of different cellular processes. This signaling pathway contributes to the modulation of cell differentiation, proliferation, survival, and motility. It provides the transduction of signals from the cell surface to the nucleus and cytoplasm as well. Moreover, abnormal regulation of this signaling pathway is a potential reason for the initiation and progression of tumoral cells. Cell surface receptors-mediated activation of small GTPase rat sarcoma oncogene (RAS) homolog leads to binding binds and the consequent rapid activation of accelerated fibrosarcoma kinase (RAF). H-, K-, and N-RAS have been considered the most related members of the RAS family, clinically. RAF has three isoforms, including a-, b-, c-RAF, considering the major role b-RAF in tumorigenesis. RAF contributes to phosphorylation of MAPK and ERK kinase (MEK), which for its parts has crucial roles in the mitogen-activated protein kinases (MAPKs) activation. The primary MAPKs members have been reported as extracellular signal-regulated kinases (ERK) 1 and 2 . Considering their important roles, ERK-1/-2 with a variety of substrates also have been considered major effectors of this pathway (Figure 4).

Activating RAS or b-RAF mutations has been significantly associated with higher RAS/RAF/MEK/ERK signaling activation. Moreover, various studies have demonstrated that K-RAS is the principal mutated RAS gene in the pancreas, lung, and colon adenocarcinoma samples (Bos, 1989; Campbell and Der, 2004). Besides, some of the receptor tyrosine kinases, such as EGFR, were correlated to the activation of RAS. Mutational activation or overexpressed level of EGFR has been associated with lower cancer prognosis. It is also associated with upregulation of signaling pathways, including RAS/RAF/MEK/ERK, PI3K/Akt/ mTOR, protein kinase $\mathrm{C}$ (PKC), phospholipase $\mathrm{D}$ signal transducer, and activator of transcription (STAT) (Roberts and Der, 2007). Curcumin has been shown to exhibit anticancer effects by interfering with signaling pathways associated with the initiation, promotion, and progression of multistage carcinogenesis. Curcumin inhibits the ERK signaling pathway, thus blocking the cell cycle and downregulates the expression of Bcl-2, concomitantly inhibiting cell proliferation and inducing apoptosis (Zhu et al., 2016).

\section{Metastasis and Wnt Signaling Pathway}

Wnt signaling pathway plays pivotal functions regulating cell polarity, cell proliferation, and cell fate determination during embryonic development. It has been shown that in the absence of the Wnt signaling pathway, the multiprotein complex has the 


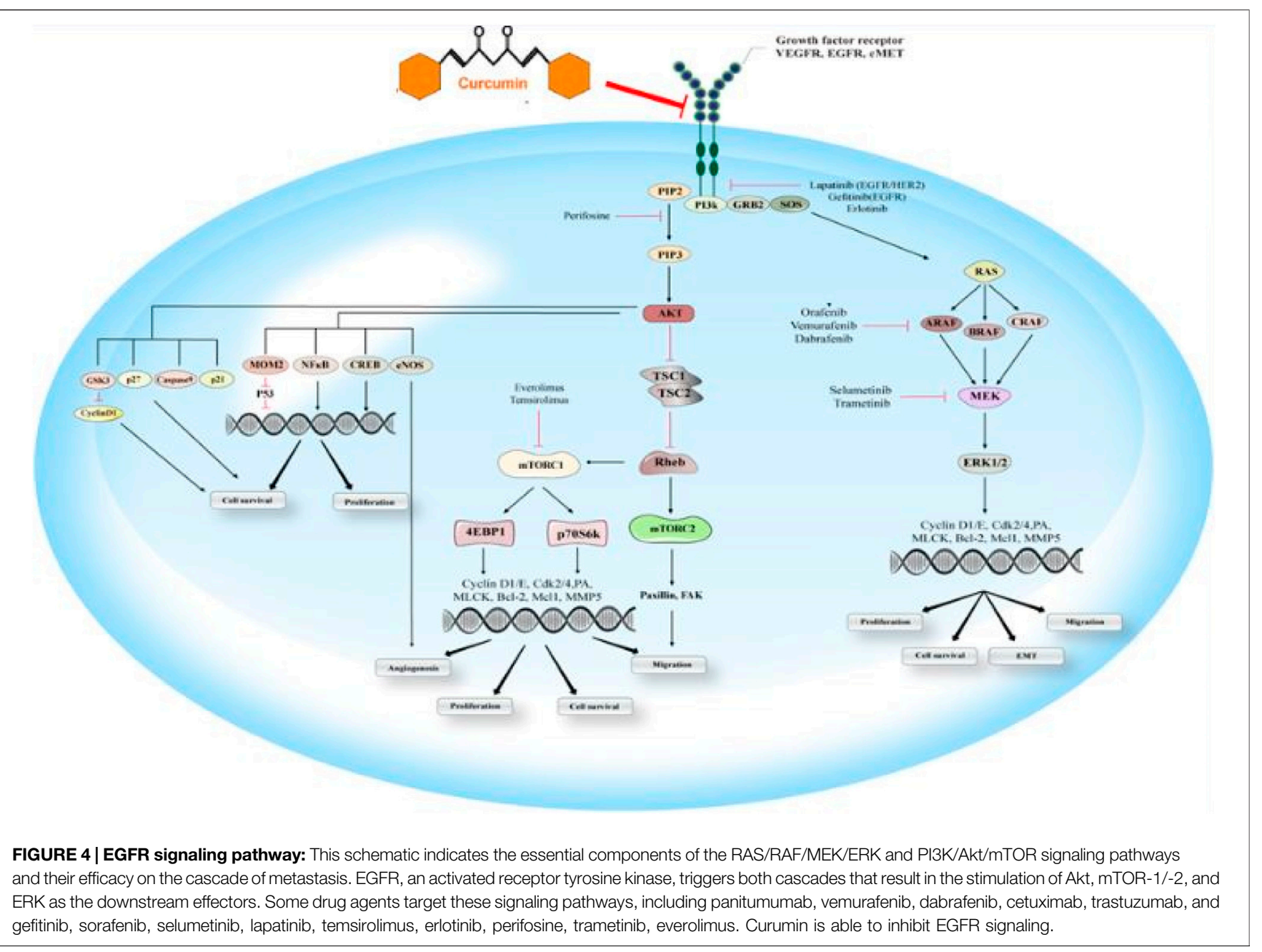

responsibility of regulating intracellular $\beta$-catenin levels. Investigations have displayed that adenomatous polyposis coli protein (APC) as a tumor suppressor, casein kinase 1 (CK1), glycogen synthase kinase-3 $\beta$ (GSK3 $\beta$ ), and the scaffolding protein Axin are involved in the multiprotein complex structure. It has been reported that Cytoplasmic $\beta$-catenin is an essential target for induction of ubiquitination and proteasomal degradation by the destruction of complex-mediated binding and phosphorylating. As this elimination process continues, $\beta$-catenin cannot reach the nucleus any longer. Another important family of transcription factors is the DNA-bound T-cell factor/lymphoid enhancer factor (TCF/LEF), which has been suggested to be one of the principal regulators of $\beta$-catenin gene expression. Lacking the nuclear $\beta$-catenin, through inactivating Groucho/TLE, as transcriptional corepressors by binding to them, TCF/LEF contributes to suppressing gene expression. Wnt has a crucial role in $\mathrm{Wnt} / \beta$-catenin pathway activation by binding its ligands to its co-receptor-low-density lipoprotein receptor-related proteins (LRP) - and also the Frizzled receptor. As a result, these receptors will be activated. Activation of $\mathrm{Wnt} / \beta$-catenin pathway significantly hinders the destruction complex, and finally can lead to enhanced aggregation and nucleic translocation of $\beta$-catenin. It has been proved that, through binding to TCF/LEF and accompanied inactivation of them, and via dislocating the Groucho/TLE, transcriptional corepressors, $\beta$-catenin activates $\mathrm{Wnt}$ target gene expression in the nucleus (Figure 5) (Daniels and Weis, 2005; Fodde and Brabletz, 2007). Curcumin inhibits tumor epithelial-mesenchymal transition by downregulating the Wnt signaling pathway and upregulating NKD2 expression in cancer cells (Zhang et al., 2016). Furthermore, curcumin suppresses cancer cell migration by inhibiting the Wnt signaling pathway (Kim et al., 2013).

\section{CURCUMIN AND METASTASIS IN GASTROINTESTINAL}

\section{Regulation of Metastasis in Pancreatic Cancer by Curcumin}

Curcumin-mediated effects on metastasis in pancreatic cancer cells are associated with their properties on various heterotypic cells-these cells, including endothelial cells, macrophages, cancer-associated fibroblasts (CAFs). CAFs have been 


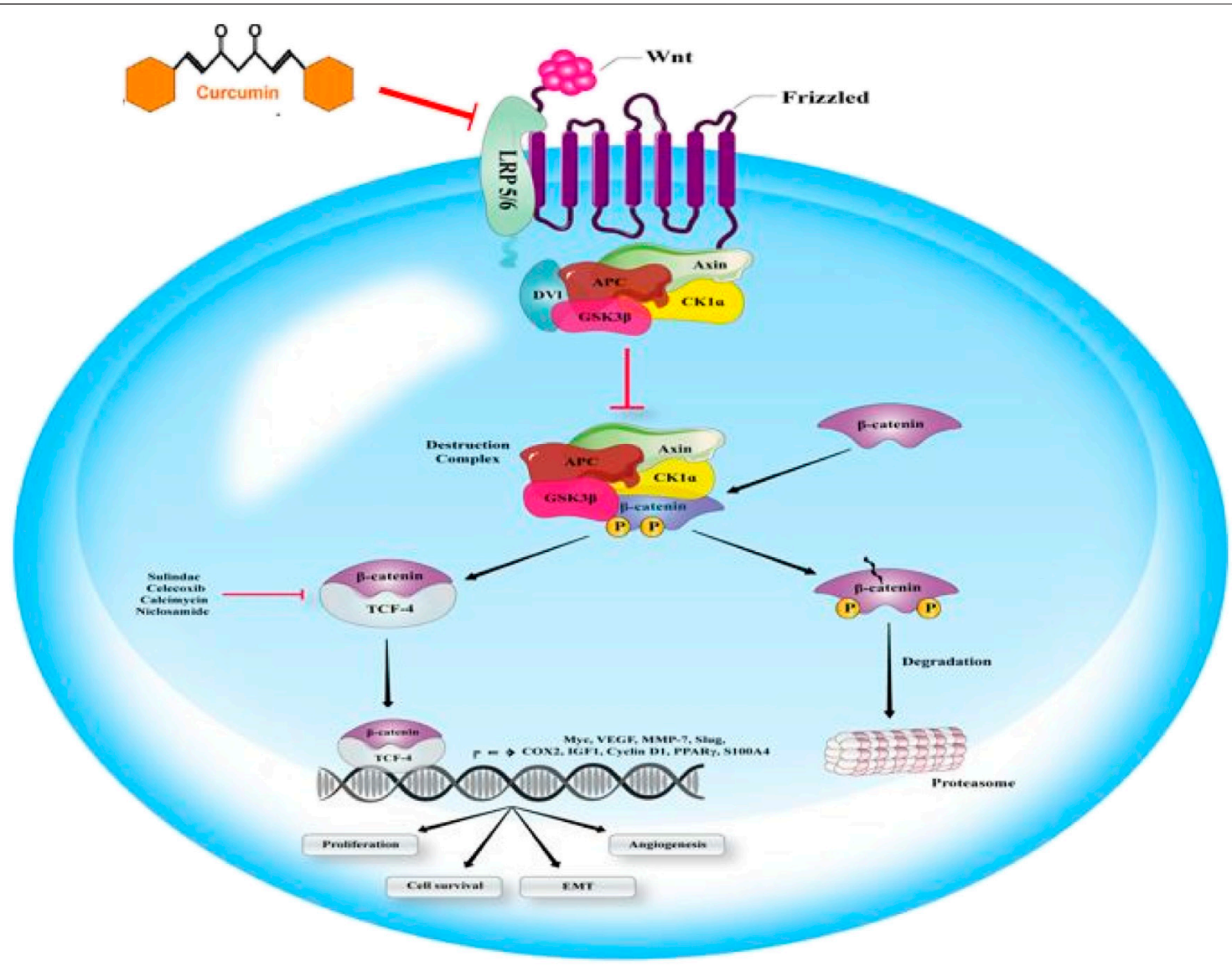

FIGURE 5 | Wnt signaling can affect the cascade of metastasis. Wnt ligand binding to the multipass receptor leads to inhibiting demolition complex and the nucleic accumulation of $\beta$-catenin, involved in Wnt gene expression. Some of the antibiotic calcimycin, NSAIDs such as celecoxib or sulindac, and the anthelminthic niclosamide play a significant role in $\beta$-catenin-induced gene transcription targeting. Curumin is able to inhibit Wnt signaling.

implicated in different malignancies, such as pancreatic ductal adenocarcinoma (PDAC), breast cancer, and gastric carcinoma (Kasashima et al., 2014; Sun et al., 2014). By targeting numerous cellular events in cancerous cells such as cell viability, tumor growth, metastasis, revascularization, immune surveillance, and CAFs, curcumin plays a crucial role in regulating tumor behavior (Lunardi et al., 2014). It has been reported that the expression level of $\alpha$-smooth muscle actin ( $\alpha$-SMA) and vimentin is significantly correlated with the process of attaining an activated phenotype by CAFs. Besides, for transforming into fibroblast-like cells, tumoral cells can potentially make use of EMT (Kalluri and Zeisberg, 2006). EMT has been introduced to be a transcriptional and epigenetic process in which some of the mesenchymal features, including enhanced motility and decreased cellular junctions, can be acquired by epithelial cells, which have important roles in the dissemination of primary tumor sites and cancer seeding at distant organs (Thiery, 2002; Friedl, 2004). In addition to CAFs capabilities for affecting the EMT of cancer cells, it has been proven that the expression of fibroblast-like cancer cells is considerably associated with higher invasion and metastatic features. Reduced expression of E-cadherin, which has been associated with tumor progression and development, is an important sign of EMT (Cowin et al., 2005; Christofori, 2006; Francí et al., 2006).

Wang and colleagues theorized that CAFs might be a possible target of curcumin for inhibiting pancreatic cancer cells' metastases (Wang et al., 2017). Their results have shown that curcumin significantly suppressed the CAF-induced promotion of metastasis and migration abilities in pancreatic cancer cells. Overall, by decreasing the mesenchymal features of CAFs, data provided substantial evidence that curcumin suppressed pancreatic cancer cells' metastasis and migration characteristics. It resulted in the reversed mediation of EMT phenotypes in pancreatic cancer cells (Wang et al., 2017).

Hypoxia is low oxygen tension traditionally found in solid tumors, which is considerably associated with decreased prognosis in cancer patients (Lei et al., 2013; Chang and Erler, 2014). Results have shown that tumor hypoxia-induced behavior of tumoral cells is significantly correlated with promoted invasion, angiogenesis, and metastasis in distant tumor sites (Chang and Erler, 2014). Hypoxia-inducible factor-1 (HIF-1) is a member of the primary helix-loop-helix-periodic acidSchiff domain transcription factor family and has been implicated in several types of solid tumors, such as pancreatic 
cancer. HIF-1haskey functions in the mediation of hypoxiainduced cellular responses (Lei et al., 2013). In their study, Sun et al. (2013) demonstrated that via inhibiting the $\mathrm{Hh}$ signaling pathway, the progression of pancreatic cancer was diminished after curcumin intervention. As a crucial pathway in tumorigenesis, the Hh signaling pathway has been shown to be implicated in pancreatic cancer samples while it is quiescent in adult pancreas cells in a normal situation (Lei et al., 2013). In a recent study, Lei et al. have shown that hypoxia-mediated invasiveness and occurrence of EMT is closely associated with the Hedgehog signaling pathway (Lei et al., 2013). Cao and colleagues hypothesized that curcumin is a prominent inhibitor for preventing hypoxia-induced invasiveness, proliferation, metastasis, and EMT progression in pancreatic cancer. Besides, they have been shown that curcumin strongly suppressed hypoxia-induced activation of Hedgehog signaling pathway. It suggested that curcumin may be a potential novel treatment for optimizing current therapeutic treatments against pancreatic cancer (Cao et al., 2016a). The results reported that in addition to its properties against hypoxia-mediated activation of Hedgehog signaling pathway, cell migration, proliferation, and invasiveness of pancreatic cancer, curcumin also mediated the EMT-related agent's expression including vimentin, E-cadherin, and $\mathrm{N}$-cadherin. Taken together, Cao and colleagues have demonstrated that via suppressing the Hh signaling pathway, curcumin plays critical roles for the inhibition of hypoxiamediated metastasis of pancreatic cancer (Cao et al., 2016a).

Hydrogen peroxide $(\mathrm{H} 2 \mathrm{O} 2)$ and superoxide anion as reactive oxygen species (ROS) are some chemically oxygen-derived reactive agents. They are generated by the mitochondrial respiratory chain. In various studies, the state of intracellular redox has been correlated with cellular signaling transduction, and regulation of multiple intracellular events (Lee and Kang, 2013). Despite their significant roles for suppressing cancer cells, via affecting cell viability, proliferation, invasion, and metastasis, sublethal concentrations production of ROS has been associated with tumor progression (Nishikawa et al., 2009). For example, Nishikawa et al. showed that sublethal concentrations of $\mathrm{H} 2 \mathrm{O} 2$ $(0-200 \mu \mathrm{M})$ resulted in pancreatic cancer development in a dosedependent manner. In contrast, $>200 \mu \mathrm{M}$ concentrations of $\mathrm{H} 2 \mathrm{O} 2$ were cytotoxic for cancerous cells ( $\mathrm{Li}$ et al., 2015).

Recently, a study demonstrated that curcumin had strong protective properties against the EMT process in the prostate cancer cells. Curcumin abrogated CAF-induced invasion and EMT, and inhibited ROS production and CXCR4 and IL-6 receptor expression in prostate cancer cells. These effects were mediated by inhibiting MAOA/mTOR/HIF-1a signaling. It was found that this protective effect correlated with MAOA/ mTOR/HIF-1a signaling pathway-induced inhibition of CAFs-mediated ROS generation (Du et al., 2015). As crucial downstream signaling cascades of ROSs, MAPK signaling pathways have been demonstrated to participate in tumor progression (Wu et al., 2008). P38 MAPK, extracellular signal-regulated kinase (ERK), and c-jun NH-2 terminal kinase (JNK) are the most critical MAPK family members. Li et al. have declared that via activating p38 MAPK and ERK signaling pathways, moderate amounts of $\mathrm{H} 2 \mathrm{O} 2$ are associated with promoted pancreatic cancer metastasis and invasion ( $\mathrm{Li}$ et al., 2015).

Cao et al. showed that curcumin intervention in Panc- 1 and BxPC-3 pancreatic cancer cells reversely regulated the cancer invasion, migration, and MMP-2 expression. Besides, H2O2mediated upregulation of phosphorylated ERK and phosphorylated NF- $\kappa \mathrm{B}$ was decreased after NAC, curcumin, and PD 98059 treatment (an ERK inhibitor). Considering this valuable information, it can be concluded that curcumin inhibited pancreatic cancer cell migration and invasiveness via inhibiting the ROS/ERK/NF- $\kappa \mathrm{B}$ signaling pathway. Furthermore, this study suggested that curcumin application might be a possible drug target for upregulating pancreatic cancer migration (Cao et al., 2016b). Table 1 lists various studies on antimetastatic effects in pancreatic cancer. Figure 6 illustrates the effects of curcumin on metastasis in GI cancers.

\section{Regulation of Metastasis in Gastric Cancer by Curcumin}

It has been demonstrated that high mobility group box 1 (HMGB1), as an essential nuclear and extracellular protein, is a crucial mediator in various pathologic and physiologic situations such as inflammation, immune response, and cancer. HMGB1 is also a diagnostic biomarker for the early stages of gastric cancer (Chung et al., 2009). Curcumin treatment in human endothelial cells caused considerable down-regulatory properties on the expression of the cell surface receptor of HMGB1 (Kim et al., 2011). Studies have reported that HMGB1 expression is highly increased in esophageal squamous cell carcinoma (ESCC). HMGB1 has a crucial role in promoting lymphangiogenesis by regulating vascular endothelial growth factors (VEGF)-C. Lymph node metastasis has been considered one of the critical determinants of progression in gastric cancer patients. Studies have declared that HMGB1 expression is associated with tumor lymphangiogenesis and new lymphatic vessel formation (Tawada et al., 2012). Curcumin treatment resulted in VEGF receptors' downregulation, including (VEGFR-2/3) and lymphangiogenic VEGF-C (Da et al., 2015). HMGB1 and VEGF-D are involved in tumor lymphangiogenesis, and VEGF-C and VEGF-D are also essential members of the VEGF family.

In a recent study, $\mathrm{Da}$ and colleagues hypothesized that by suppression of HMGB1/VEGF-D signaling, curcumin might have potential anti-lymphangiogenesis properties. Therefore, it can be applied as a potential treatment in patients with gastric cancer (Da et al., 2019). Results have demonstrated that curcumin treatment in AGS and SGC-7901 gastric cancer cells caused a significant cell viability reduction through activating caspase-3. In contrast, it resulted in an apoptosis increase in a concentrationdependent manner. Besides, curcumin intervention remarkably eliminated the HMGB1 and VEGF-D expression levels. Considering their findings, they have suggested that curcumin might be an anti-lymphangiogenesis agent in the treatment of gastric cancer by inhibiting HMGB1/VEGF-D signaling ( $\mathrm{Da}$ et al., 2019). 
TABLE 1 | Curcumin and metastasis in pancreatic cancer.

\begin{tabular}{|c|c|c|c|c|c|c|}
\hline $\begin{array}{l}\text { Type of } \\
\text { curcumin }\end{array}$ & Dose & Target & Model & Cell line & Results & Ref \\
\hline Curcumin & 5 and $10 \mu \mathrm{M}$ & $\begin{array}{l}\text { E-cadherin and } \\
\text { Vimentin }\end{array}$ & $\begin{array}{l}\text { In vitro, In } \\
\text { vivo }\end{array}$ & $\begin{array}{l}\text { Capan1 and } \\
\text { Panc1 }\end{array}$ & - Blocked migration and metastasis & $\begin{array}{l}\text { Wang et al. } \\
(2017)\end{array}$ \\
\hline $\begin{array}{l}\text { Irinotecan and } \\
\text { curcumin in ultra- } \\
\text { small PEGylated } \\
\text { NDs, curcumin }\end{array}$ & $15 \mathrm{mg} / \mathrm{kg}$ & Kras and Trp53 & $\begin{array}{l}\text { In silico, } \\
\text { In vitro, } \\
\text { and In } \\
\text { vivo }\end{array}$ & $\begin{array}{l}\text { AsPC-1 and } \\
\text { PANC-1 }\end{array}$ & $\begin{array}{l}\text { - Antitumor efficacy } \\
\text { - Downregulation of modulator of the } \\
\text { tumor microenvironment }\end{array}$ & $\begin{array}{l}\text { Madamsetty et al. } \\
\text { (2019) }\end{array}$ \\
\hline Curcumin & $20 \mu \mathrm{M}$ & $\begin{array}{l}\text { E-cadherin, } \\
\mathrm{N} \text {-cadherin, vimentin, } \\
\text { and Hh signaling- } \\
\text { related factors }(\mathrm{SHH} \text {, } \\
\mathrm{SMO}, \mathrm{GLI} 1)\end{array}$ & In vitro & Panc-1 & $\begin{array}{l}\text { - Inhibition of cell proliferation, } \\
\text { migration, and invasion }\end{array}$ & Cao et al. (2016a) \\
\hline Curcumin & $5,10,20$, and $40 \mu \mathrm{M}$ & $\begin{array}{l}(\mathrm{MMP})-2, \mathrm{MMP}-9, \mathrm{p}- \\
\text { ERK, and p-NF-kB }\end{array}$ & In vitro & $\begin{array}{l}\text { BxPC-3and } \\
\text { Panc-1 }\end{array}$ & $\begin{array}{l}\text { - Inhibition of cell invasion and } \\
\text { migration }\end{array}$ & Cao et al. (2016b) \\
\hline $\begin{array}{l}\text { Curcumin, EF31, } \\
\text { and UBS109 }\end{array}$ & $\begin{array}{l}10 \mu \mathrm{M} \text { curcumin, } 750 \mathrm{nM} \\
\text { EF31, and } 250 \text { nM UBS109 } \\
\text { in MIAPaCa-2 cells. } 20 \mu \mathrm{M} \\
\text { curcumin, } 1.25 \mu \mathrm{M} \text { EF31, } \\
\text { and } 250 \text { nMUBS109 in } \\
\text { PANC-1 cells ( }\end{array}$ & $\begin{array}{l}\text { TGF } \beta \text {, angiopoietin } 1 \text {, } \\
\text { angiopoietin } 2, \text { HIF- } \\
\text { 1 } \alpha, \text { Hsp90, COX-2, } \\
\text { VEGF, and NF-кB }\end{array}$ & In vitro & $\begin{array}{l}\text { MIA PaCa-2 and } \\
\text { PANC-1 }\end{array}$ & $\begin{array}{l}\text { - Antiangiogenic activities } \\
\text { - Downregulation of HIF-1a, Hsp90, } \\
\text { COX-2, and VEGF }\end{array}$ & $\begin{array}{l}\text { Nagaraju et al. } \\
(2015)\end{array}$ \\
\hline Curcumin & $20 \mu \mathrm{M}$ & $\begin{array}{l}\text { E-cadherin, } \\
\mathrm{N} \text {-cadherin, vimentin, } \\
\text { and PI3K/AKt/NF- } \mathrm{B} \\
\text { signaling pathway }\end{array}$ & In vitro & $\begin{array}{l}\text { BxPC-3 and } \\
\text { Panc-1 }\end{array}$ & $\begin{array}{l}\text { - Inhibition of epithelial-to- } \\
\text { mesenchymal transition via the PI3K } \\
\text { Akt/NF-kB pathway }\end{array}$ & Li et al. (2018a) \\
\hline $\begin{array}{l}\text { Curcumin loaded } \\
\text { chitosan/PEG } \\
\text { blended PLGA } \\
\text { nanoparticles }\end{array}$ & $10 \mathrm{mg}$ & $\begin{array}{l}\text { Bcl2, Bax, PARP, and } \\
\text { Caspase-3 }\end{array}$ & In vitro & $\begin{array}{l}\text { PANC-1 and mia } \\
\text { Paca-2 }\end{array}$ & $\begin{array}{l}\text { - Enhanced antimigratory, anti- } \\
\text { invasive, and apoptosis effect }\end{array}$ & Arya et al. (2018) \\
\hline Curcumin & $2.5,5,15,30$, and $50 \mu \mathrm{M}$ & $\begin{array}{l}\text { Caspase-3 and } \\
\text { Caspase- } 9\end{array}$ & In vitro & $\begin{array}{l}\text { BxPC-3 and } \\
\text { Panc-1 }\end{array}$ & $\begin{array}{l}\text { - Curcumin and garcinol in } \\
\text { combination exhibit a high level of } \\
\text { synergism, with enhanced bioactivity }\end{array}$ & $\begin{array}{l}\text { Parasramka and } \\
\text { Gupta (2012) }\end{array}$ \\
\hline Curcumin & $0-100 \mu \mathrm{M}$ & $\begin{array}{l}\text { TNFR, caspase-8, } \\
\text { caspase-3, BID, Bax, } \\
\text { NFKB, NDRG 1, and } \\
\text { BCL2L10 }\end{array}$ & In vitro & $\begin{array}{l}\text { BxPC-3 and } \\
\text { MiaPaCa-2 }\end{array}$ & $\begin{array}{l}\text { - Upregulation of the extrinsic } \\
\text { apoptotic pathway }\end{array}$ & $\begin{array}{l}\text { Youns and Fathy } \\
\text { (2013) }\end{array}$ \\
\hline Curcumin & 10,20 , and $30 \mu \mathrm{mol} / \mathrm{ml}$ & $\begin{array}{l}\text { Shh, GLI1, } \\
\text { E-cadherin, and } \\
\text { vimentin }\end{array}$ & In vitro & PANC-1 & $\begin{array}{l}\text { - Reversed the } \\
\text { epithelial-mesenchymal transition of } \\
\text { pancreatic cancer cells by inhibiting } \\
\text { the hedgehog signaling pathway }\end{array}$ & Sun et al. (2013) \\
\hline $\begin{array}{l}\text { Polymeric } \\
\text { nanoparticle- } \\
\text { encapsulated } \\
\text { curcumin }\end{array}$ & $\begin{array}{l}150 \mu \mathrm{L} \text { nanocurcumin and } \\
25 \mathrm{mg} / \mathrm{kg} \text { curcumin }\end{array}$ & $\begin{array}{l}\text { NFkB, MMP-9, and } \\
\text { cyclin D1 }\end{array}$ & In vivo & - & $\begin{array}{l}\text { - Blocked tumor growth and } \\
\text { metastasis }\end{array}$ & Bisht et al. (2010) \\
\hline Curcumin & 50,100 , or $200 \mathrm{nM}$ & $\begin{array}{l}N F-\kappa B \text {, caspase- } 3 \text {, } \\
\text { and }-7\end{array}$ & In vitro & $\begin{array}{l}\text { Panc-1, BxPC-3, } \\
\text { and MIA PaCa-2 }\end{array}$ & $\begin{array}{l}\text { - Inhibited cell viability/survival, } \\
\text { robustly activated caspase-3/7 } \\
\text { activity, and subsequent cell death }\end{array}$ & $\begin{array}{l}\text { Veeraraghavan } \\
\text { et al. (2011) }\end{array}$ \\
\hline $\begin{array}{l}\text { CDF (a synthetic } \\
\text { curcumin-derived } \\
\text { analogue) }\end{array}$ & $0.5-2 \mu \mathrm{M}$ & $\begin{array}{l}\text { PTEN, MT1-MMP, } \\
\text { miR-200 family, and } \\
\beta \text {-actin }\end{array}$ & In vitro & $\begin{array}{l}\text { AsPC-1, BxPC-3, } \\
\text { COLO-357, } \\
\text { MIAPaCa-2, } \\
\text { MIAPaCa-GR, } \\
\text { and PANC-1 }\end{array}$ & $\begin{array}{l}\text { - Re-expression of miR-200c } \\
\text { - Downregulated the expression of } \\
\text { MT1-MMP was }\end{array}$ & $\begin{array}{l}\text { Soubani et al. } \\
(2012)\end{array}$ \\
\hline Curcumin & $?$ & $\begin{array}{l}\text { ERK, NF-kB, } \\
\text { E-cadherin, vimentin, } \\
\text { MMP-9, and IL-6 }\end{array}$ & In vitro & $\begin{array}{l}\text { BxPC-3 and } \\
\text { Panc-1 }\end{array}$ & - Inhibition of growth and metastasis & $\begin{array}{l}\text { Mardani et al. } \\
(2020)\end{array}$ \\
\hline $\begin{array}{l}\text { CDF (a synthetic } \\
\text { curcumin-derived } \\
\text { analogue) }\end{array}$ & $0.5 \mu \mathrm{M}$ & $\begin{array}{l}\text { VEGF, IL-6, Oct4, } \\
\text { EZH2, miR-21, miR- } \\
210 \text { u, Nanog, EZH2, } \\
\text { and HIF1- } \alpha\end{array}$ & $\begin{array}{l}\text { In vitro } \\
\text { and In } \\
\text { vivo }\end{array}$ & $\begin{array}{l}\text { AsPC-1 and } \\
\text { MiaPaCa-2 }\end{array}$ & $\begin{array}{l}\text { - Attenuated the aggressiveness of } \\
\text { cancer cells through decreasing the } \\
\text { expression of VEGF, IL-6, and } \\
\text { miR-21 }\end{array}$ & Bao et al. (2012) \\
\hline
\end{tabular}

Late-stage diagnosis, which is seen in most gastric cancer patients, causes poor prognosis and therapeutic outcome. This problem results in tumor cell dissemination into circulation and distant organs as circulating tumor cells (CTCs), which leads to cancer seeding, and formation of a distal tumor, especially in hepatic tissue (Saito et al., 2013; Hatakeyama et al., 2015; Xia et al., 2015). In addition to their presence in blood circulation, CTCs have been identified with a number of specific cell surface markers. Among 


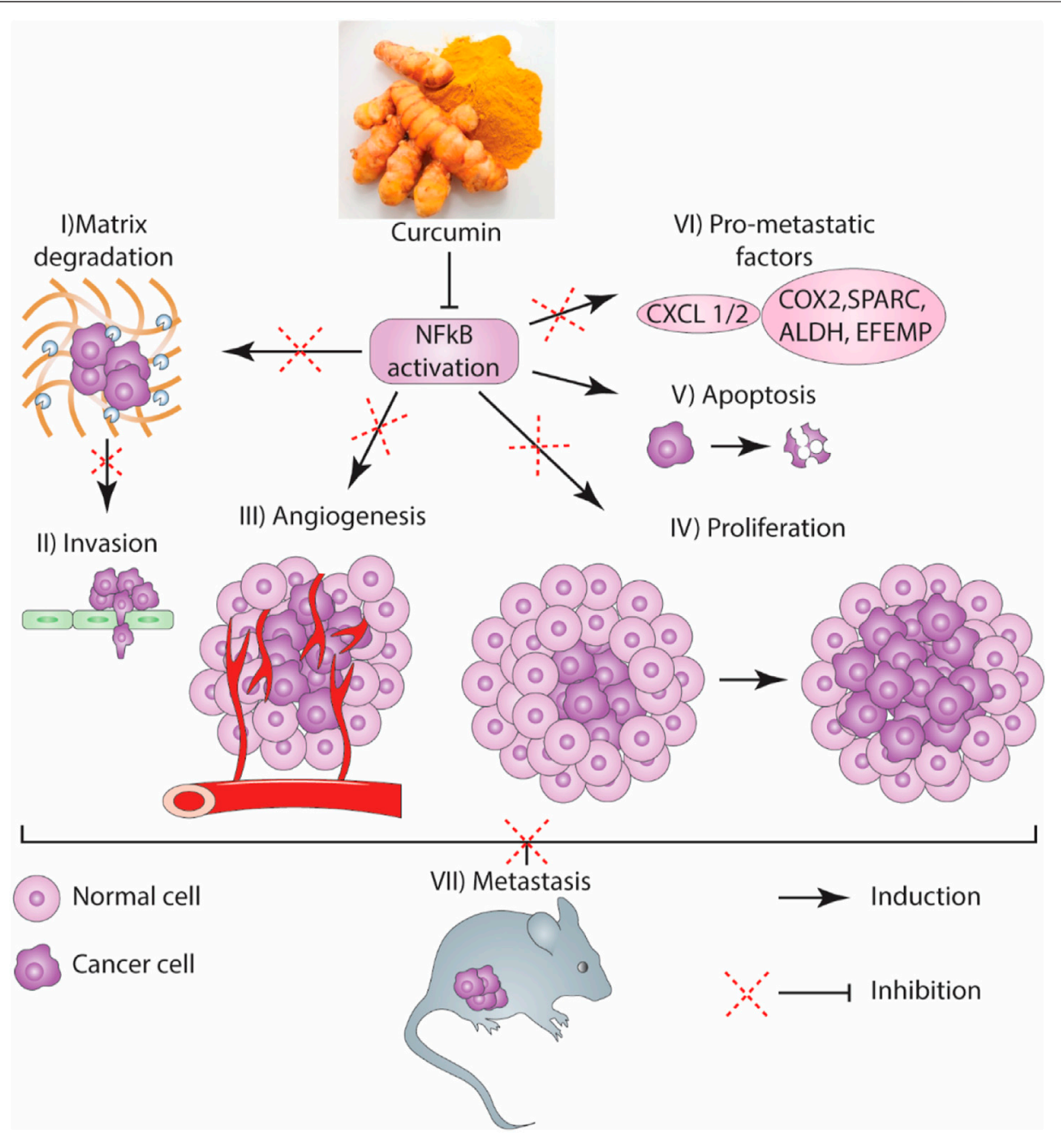

FIGURE 6 | A schema of the antimetastatic effects of curcumin in Gl cancers.

them, CXCR4, which is known as the stromal cell-derived factor-1 (SDF-1) receptor, has been characterized by different cancer types (Reckamp et al., 2009; Franco et al., 2012; Mego et al., 2016). In their previous study, Zhu et al. have declared that $\mathrm{CD} 90^{+}$and CXCR4+ hepatocellular carcinoma (HCC) cells may be CTCs. Therefore, selective inhibition of $\mathrm{CD}^{+} 0^{+}$and CXCR4+ cells, resulting in reduced cancer metastasis, may provide significant improvements in the current therapeutic approaches in HCC patients (Zhu et al., 2015).

$\mathrm{Gu}$ et al. have evaluated the antimetastatic capabilities of curcumin in the reduction of tumor formation in liver in mice-bearing proximal gastric carcinoma (PGC) (Gu et al., 2019). Results showed that formation of hepatic tumor and presence of CTCs were considerably reduced after curcumin treatment. Furthermore, treatment with curcumin in PGCs in vivo and in vitro downregulated the CXCR4 expression, and hence by inhibiting the SDF-1/CXCR4 signaling pathway, suppressed metastasis of PGC (Gu et al., 2019).

By suppressing the activity of MMP-2, curcumin administration has been associated with inhibiting cancer progression (Mitra et al., 2006; Lee et al., 2015a; Liu et al.,
2017). Moreover, due to its low solubility, bioavailability and efficacy of curcumin is decreased. Various in vivo investigations have demonstrated that induction of structural modifications in the $\beta$-diketone moiety, aromatic rings, or the flanking double bonds coupled with the $\beta$-diketone moiety of curcumin may be an optimal strategy for improving its bioavailability and anticancer activities. Selected CH-5 (4,4' ${ }^{\prime}$-[(2-Oxo-1,3cyclohexanediylidene)-di(E) methylylidene]dibenzonitrile) and monoketone curcumin analogs have been screened to be evaluated for their anticancer properties in numerous tumor cell lines (Lima et al., 2018).

Silva and colleagues investigated the antimetastatic properties of CH-5 in human HGC-27 gastric cancer cell line (Silva et al., 2018). Initially, they have observed cell viability was decreased, while apoptosis was increased in a dose-dependent way. Additionally, through decreased expression and collagenase activity of MMP-2, a remarkable decrease in the invasiveness and migration of HGC-27 cells was observed after $\mathrm{CH}-5$ treatment. Herein, via the upregulation of apoptosis and the downregulation of invasion and migration, $\mathrm{CH}-5$ treatment in 
TABLE 2 | Curcumin inhibits gastric cancer metastases.

\begin{tabular}{|c|c|c|c|c|c|c|c|}
\hline Type of curcumin & Dose & Target & Model & Cell line & $\begin{array}{l}\text { Sample } \\
\text { size }\end{array}$ & Results & Ref \\
\hline Curcumin & $10-50 \mu \mathrm{M}$ & $\begin{array}{l}\text { Caspase-3, VEGF-D, and } \\
\text { HMGB1 }\end{array}$ & In vitro & $\begin{array}{l}\text { AGS and } \\
\text { SGC-7901 }\end{array}$ & - & $\begin{array}{l}\text { - Anti-lymphangiogenesis } \\
\text { effects } \\
\text { - Decreased cell viability and } \\
\text { apoptosis through the } \\
\text { activation of caspase-3 }\end{array}$ & $\begin{array}{l}\text { Da et al. } \\
(2019)\end{array}$ \\
\hline $\begin{array}{l}\text { Curcumin and liposomal } \\
\text { curcumin }\end{array}$ & $\begin{array}{l}0.5 \mu \mathrm{mol} / \mathrm{L} \\
\text { in vitro and } \\
10 \mathrm{mg} / \mathrm{kg} \text { in vivo }\end{array}$ & CXCR4, GAPDH, and SDF1 & $\begin{array}{l}\text { In vitro, } \\
\text { In vivo }\end{array}$ & PGCs & 30 & $\begin{array}{l}\text { - Inhibited metastasis through } \\
\text { reducing circulating tumor } \\
\text { cells }\end{array}$ & $\begin{array}{l}\text { Gu et al. } \\
(2019)\end{array}$ \\
\hline $\begin{array}{l}\text { Curcumin-loaded } \\
\text { nanoemulsion and } \\
\text { curcumin }\end{array}$ & $12.5 \mu \mathrm{M}$ & NA & $\begin{array}{l}\text { In vitro, } \\
\text { In vivo }\end{array}$ & AGS & 10 & $\begin{array}{l}\text { - Prevent tumor reincidence } \\
\text { and metastasis }\end{array}$ & $\begin{array}{l}\text { Guerrero } \\
\text { et al. (2018) }\end{array}$ \\
\hline $\mathrm{CH}-5$ & $\begin{array}{l}0,2.5,5,10,20 \\
40, \text { and } 50 \mu \mathrm{M}\end{array}$ & Caspase-3, MMP-2 & In vitro & HGC-27 & - & $\begin{array}{l}\text { - Suppressed proliferation, } \\
\text { migration, and invasion }\end{array}$ & $\begin{array}{l}\text { Silva et al. } \\
(2018)\end{array}$ \\
\hline Curcumin & $\begin{array}{l}40,80, \text { and } \\
160 \mathrm{mg} / \mathrm{kg} \\
\text { per day }\end{array}$ & $\begin{array}{l}\text { VEGFR-3, Prox-1, podoplanin, } \\
\text { and LYVE-1 }\end{array}$ & $\begin{array}{l}\text { In vitro, } \\
\text { In vivo }\end{array}$ & SGC7901 & 10 & $\begin{array}{l}\text { - Suppressed lymphatic } \\
\text { vessel density }\end{array}$ & $\begin{array}{l}\text { Da et al. } \\
(2015)\end{array}$ \\
\hline B19 & 5,10, or $20 \mu \mathrm{M}$ & TrxR1 & $\begin{array}{l}\text { In vitro, } \\
\text { In vivo }\end{array}$ & $\begin{array}{l}\text { SGC-7901, } \\
\text { BGC-823, and } \\
\text { KATO III }\end{array}$ & - & $\begin{array}{l}\text { - Induced ROS-dependent } \\
\text { apoptosis and cell cycle arrest }\end{array}$ & $\begin{array}{l}\text { Chen et al. } \\
(2016)\end{array}$ \\
\hline $\begin{array}{l}\text { Hydrazinocurcumin } \\
\text { (CTK7A) }\end{array}$ & $100 \mu \mathrm{M}$ & $\begin{array}{l}\text { p300, Hif1a, Noxa, Twist1, } \\
\text { caspase-3, caspase-9, } \\
\text { Cytochrome c, N-cadherin, } \\
\text { E-cadherin, p-p38 MAPK, p- } \\
\text { ERK, p-phospho JNK, GAPDH, } \\
\text { and Cox IV }\end{array}$ & In vitro & $\begin{array}{l}\text { GCCS AGS, } \\
\text { MKN } 45 \\
\text { KATO III }\end{array}$ & - & $\begin{array}{l}\text { - Reduced invasiveness of } \\
\text { cancer cells and induced } \\
\text { apoptosis }\end{array}$ & $\begin{array}{l}\text { Rath et al. } \\
(2017)\end{array}$ \\
\hline
\end{tabular}

gastric cancer cells showed anticancer properties. It implies that the application of $\mathrm{CH}-5$ molecule can be considered an optimal antimetastatic medicine for the prevention of gastric cancer development (Silva et al., 2018). Table 2 lists various studies on antimetastatic effects of in gastric cancer.

\section{Regulation of Metastasis in Colorectal Cancer by Curcumin}

Cancer stem cells (CSCs) are a small subpopulation of immortal cells. They are essential agents in chemoresistance, tumor invasion, and relapse. CSCs have crucial functions in metastasis induction, which is considered the leading factor of cancer-related mortalities (Muñoz et al., 2012). Numerous studies have shown that curcumin targeted Wnt/ $\beta$-catenin, Notch, and Sonic Hedgehog (SHH) signaling pathways. These are involved in the self-renewal of tumoral cells, targeting CSCs to prevent cancer invasion (Takebe et al., 2015). Some investigators believe the antiinflammatory properties of curcumin are additionally engaged in its antimetastatic characteristics.

It has been demonstrated that overexpression of insulin-like growth factor-1 (IGF-1) and insulin is an essential agent in cancer progression and metastasis (Adachi et al., 2002; Sarfstein et al., 2010; Liu et al., 2011; Orrù and Nigro, 2017). There is a lot of resemblance in action between insulin and IGF-1 signaling; herein, there is a possibility of recruitment of each other's receptors by their ligands (Panda et al., 2013). Besides, through affecting similar mechanisms, both these receptors play crucial roles in the activation of similar intracellular pathways (Han et al., 2017). Inhibition of IGF-1 in some specific cancer types, such as pancreatic carcinomas, led to decreased cancer growth and metastasis. In contrast, the role of insulin receptor downregulation in the suppression of cancer development has not yet been fully understood (Subramani et al., 2014). Larsson and colleagues demonstrated that hyperinsulinemia is positively associated with progression of colorectal cancer in diabetic patients (Larsson et al., 2005). They also reported that through modulating mitogen-activated protein kinase (MAPK) and IRS1/phosphoinositide 3-kinase (PI3K)/Akt signaling pathways, insulin significantly increases the mRNA expression of (MMP-2) in HCT-116 human colorectal cells (Larsson et al., 2005).

Various investigations have suggested that anti-inflammatory properties of curcumin are involved into its inhibitory effects on migration of tumoral cells. Insulin and IGF-1 receptors and signaling pathways were regulated by curcumin. As an essential pathway, insulin signaling participates in tumor progression and initiation. To that end, Hosseini and colleagues hypothesized that via downregulating insulin and IGF-1 receptors, curcumin could show its antimetastatic properties (Hosseini et al., 2019). In their study, the effects of curcumin treatment were measured in 5-fluorouracil (5-FU)treated viable resistant SW480 colorectal cells. Their results showed that the expression of avian myelocytomatosis virus oncogene cellular homolog (MYC), IGF-1 receptors, and insulin was remarkably decreased after treatment with curcumin. Therefore, insulin and IGF-1 receptors downregulation in chemoresistant colorectal cancer cells caused a greater reduction in the migration and proliferation of tumoral cells (Hosseini et al., 2019). 
Application of curcumin in combination with different medicines including 5-FU (Toden et al., 2015), to Ifenamic acid (Sankpal et al., 2016), and ulinastatin (Shen et al., 2014) can make its utilization more effective, reverse chemoresistance, inhibit cell growth, and metastasis. More than 300 numerous constituents, including free arabinose (1\%), curcumin (3-5\%), essential oil (2-7\%), and acid glycans named ukonan, were extracted from turmeric, which is known as the significant source of curcumin (Kim et al., 2012b). Moreover, various studies demonstrated that besides curcumin, different components in turmeric have been introduced to be more potent for displaying antitumor activities, and can be used as potential enhancer of curcumin bioavailability (Anand et al., 2007; Kim et al., 2012b). Yue et al. demonstrated that the accumulation of curcumin within colonic cells was increased in the presence of turmerones in the extract of turmeric (Yue et al., 2012). Furthermore, curcumin plus turmerones or curcumin in the extract of turmeric can promote the antitumor properties in the colorectal cancer model in vivo (Yue et al., 2016). Thus far, a few investigations evaluated the turmeric extract antimetastatic properties on colorectal cancer. According to Kim et al., CXC motif receptor 4 (CXCR4) expression, as a chemokine receptor that has a role in metastasis in vitro, was inhibited after turmeric extract treatment (Kim et al., 2012b).

Using an aggressive orthotopic CRC model with spontaneous metastasis, $\mathrm{Li}$ et al. evaluated antimetastatic and antitumor properties of turmeric extract and first-line chemotherapeutics (FOLFOX) (134). Their results showed turmeric extract significantly induced a cytotoxic effect, suppressed colony formation, reduced cell motility, migration, and EMT in murine colorectal cancer cells. Turmeric extract showed all these functions using various signaling pathways such as cofilin, ERK, FAK/p-Src, STAT3, and AKT. Besides, in vivo treatment with turmeric extract $(200 \mathrm{mg} / \mathrm{kg})$ caused a great reduction burden of a colon tumor, and suppressed hepatic and lung metastasis. Also, turmeric extract treatment significantly promoted immune response via stimulating $\mathrm{T}$ cell, altered tumor microenvironment, and displayed antimetastatic properties. For evaluating its antitumoral and antimetastatic properties, turmeric extract was applied for the first time in vivo and in vitro. These results suggested that turmeric extract can be used as an essential factor for the treatment or prevention of metastasis in colorectal cancer patients (Li et al., 2018b).

As mentioned earlier, the poor water solubility of curcumin has limited its bioavailability after oral intake and therefore, correlated with low efficacy of therapeutic usage of this compound (Wang et al., 1997; Aggarwal et al., 2007). For overcoming pharmacokinetic and bioavailability restrictions of curcumin's oral administration, investigators have formulated a curcumin liposome for intravenous application and introduced an optimal drug delivery strategy (Li et al., 2005; Li et al., 2007; Mach et al., 2009; Helson et al., 2012; Ranjan et al., 2013; Storka et al., 2015). Different studies evaluated the efficacy of liposomal curcumin anticancer activities in pancreatic cell lines (MiaPaCa-2 or BxPC-3) xenograft models (Li et al., 2005; Mach et al., 2009;
Ranjan et al., 2013). Two and eighth after liposomal curcumin constant infusions in beagle dogs, Helson et al. evaluated curcumin and its active metabolite tetrahydrocurcumin pharmacokinetics, organ, and tissue distribution. Results demonstrated that $2 \mathrm{~h}$ infusions caused greater curcumin and tetrahydrocurcumin plasma concentrations compared with $8 \mathrm{~h}$ infusions (Helson et al., 2012), although after the $8 \mathrm{~h}$ infusions, organ and tissue curcumin and THC distributions were overall higher than $2 \mathrm{~h}$ infusions (Matabudul et al., 2012). Curcumin liposomes were tested in a placebo-controlled, randomized, doseescalation, double-blind study in 49 healthy female and male subjects. Volunteers received an individual IV dose of curcumin liposomes $\left(10-400 \mathrm{mg} / \mathrm{m}^{2} ; n=2-6\right.$ per group, total $\left.n=39\right)$ or placebo $(n=10)$ for $2 \mathrm{~h}$. It was tolerated well, but at dosages $\geq 120 \mathrm{mg} / \mathrm{m}^{2}$, a transient red blood cell echinocyte formation occurred with both liposomes and curcumin. Besides, the mean cellular volume was increased (Storka et al., 2015).

In a study, tolerability and safety of increasing concentrations of liposomal curcumin were investigated in metastatic cancer patients (Greil et al., 2018). Curcumin pharmacokinetics and anticancer activities were investigated as secondary aims in different studies. This clinical trial was conducted as a phase I, open-label study, and single-center. The liposomal curcumin intravenous infusion was performed weekly in patients with metastatic tumors for 8 weeks. Initiate dose was $100 \mathrm{mg} / \mathrm{m}^{2}$ over $8 \mathrm{~h}$, following continuous increasing concentrations, the dose raised to $300 \mathrm{mg} / \mathrm{m}^{2}$ over $6 \mathrm{~h}$. At $100-300 \mathrm{mg} / \mathrm{m}^{2}$ concentrations over $8 \mathrm{~h}$, no dose-limiting toxicity was reported in 26 subjects. While hemolysis was developed in one of the patients who received $300 \mathrm{mg} / \mathrm{m}^{2}$ over $6 \mathrm{~h}$, furthermore in three patients who received the same concentrations hemoglobin was decreased $>2 \mathrm{~g} / \mathrm{dl}$. Pharmacokinetic analyses demonstrated that after the infusion, plasma concentrations of curcumin were decreased to undetectable levels. Based on RECIST V1.1, curcumin did not show antitumor activities. Transient clinical benefit and tumor marker responses improved significantly in two subjects. The maximum tolerated concentration of liposomal curcumin was $300 \mathrm{mg} / \mathrm{m}^{2}$ over $6 \mathrm{~h}$ in pretreated patients, and therefore, starting with this dose is suggested for performing anticancer clinical trials (Greil et al., 2018). Table 3 lists various studies on antimetastatic effects in colorectal cancer.

\section{Regulation of Metastasis in Oral Cancer by Curcumin}

Slug, Twist, and Snail transcription factors have been introduced as direct suppressors of E-cadherin through interacting between their COOH-terminal with a $5^{\prime}$-CACCTG- $3^{\prime}$ sequence in the promoter of E-cadherin (Yang et al., 2004). Various studies have reported that numerous EMT modulators, including Twist, Slug, E-cadherin, and Snail, have pivotal functions in inhibiting cancer invasion and metastatic capabilities. Through decreasing the level of E-cadherin expression, overexpression of Snail or Twist has been reported to be an essential agent for induction of tumor progression, further aberrant regulation of Snail or Twist has also been demonstrated in different types of epithelial tumors, such as gastric (Rosivatz et al., 2002), prostate (Yuen et al., 2007), breast 
TABLE 3 | Curcumin-induced antimetastatic effects against colorectal cancer.

\begin{tabular}{|c|c|c|c|c|c|c|c|}
\hline Type of curcumin & Dose & Target & Model & Cell line & $\begin{array}{l}\text { Sample } \\
\text { size }\end{array}$ & Results & Ref. \\
\hline Curcumin & $2.5-75 \mu \mathrm{M}$ & Metastatic features & In vitro & HCT-116 and LoVo & - & $\begin{array}{l}\text { - Increased metastasis of cancer } \\
\text { cells }\end{array}$ & $\begin{array}{l}\text { Calibasi-Kocal } \\
\text { et al. (2019) }\end{array}$ \\
\hline Curcumin & $\begin{array}{l}3,6 \text {, and } 9 \mu \mathrm{g} / \\
\mathrm{ml} \text { in vitro and } \\
200 \mathrm{mg} / \mathrm{kg} \\
\text { in vivo }\end{array}$ & $\begin{array}{l}\text { CDC42, RhoA, } \\
\text { Rac123,TIMP2, FAK, } \\
\beta \text {-catenin, p-STAT3, } \\
\text { STAT3, JNK, p-JNK, } \\
\text { Erk, } p \text {-Erk, Src, } p \text {-Src, } \\
\text { Akt, } p \text {-Akt, Rock, } \\
\text { N-Cadherin, and } \\
\text { E-Cadherin }\end{array}$ & $\begin{array}{l}\text { In vitro, } \\
\text { In vivo }\end{array}$ & $\begin{array}{l}\text { HCT116, HT-29, } \\
\text { and colon 26-M01 }\end{array}$ & 3 & $\begin{array}{l}\text { - Exhibited cytotoxic effect, } \\
\text { inhibited colony formation, } \\
\text { decreased cell motility, } \\
\text { migration, and } \\
\text { epithelial-mesenchymal } \\
\text { transitions }\end{array}$ & Li et al. (2018b) \\
\hline Liposomal curcumin & $\begin{array}{l}100 \mathrm{mg} / \mathrm{m}^{2} \\
\text { over } 8 \mathrm{~h} \text {, then } \\
\text { increased to } \\
300 \mathrm{mg} / \mathrm{m}^{2} \\
\text { over } 6 \mathrm{~h}\end{array}$ & NA & Human & - & 32 & $\begin{array}{l}\text { - } 300 \mathrm{mg} / \mathrm{m}^{2} \text { liposomal } \\
\text { curcumin over } 6 \mathrm{~h} \text { was the } \\
\text { maximum tolerated dose in } \\
\text { these heavily pretreated patients }\end{array}$ & Greil et al. (2018) \\
\hline Curcumin & $\begin{array}{l}1,5,10,15,20 \\
25,30 \\
\text { and } 50 \mu \mathrm{M}\end{array}$ & $\begin{array}{l}\text { MYC, insulin, and IGF-1 } \\
\text { receptors }\end{array}$ & In vitro & SW480 & - & $\begin{array}{l}\text { - Decreased in the proliferation } \\
\text { and migration through } \\
\text { downregulation of the insulin } \\
\text { and insulin-like growth factor-1 } \\
\text { receptors }\end{array}$ & $\begin{array}{l}\text { Hosseini et al. } \\
(2019)\end{array}$ \\
\hline Calebin A & $\begin{array}{l}0.01,0.1,1,2 \\
5, \text { and } 10 \mu \mathrm{M}\end{array}$ & TNF- $\beta$ and p65-NF- $\kappa B$ & In vitro & $\begin{array}{l}\text { HCT116, RKO, and } \\
\text { SW480 }\end{array}$ & - & $\begin{array}{l}\text { - Suppressed NF-B mediated } \\
\text { proliferation, invasion, and } \\
\text { metastasis }\end{array}$ & $\begin{array}{l}\text { Buhrmann et al. } \\
\text { (2019) }\end{array}$ \\
\hline Curcumin & $\begin{array}{l}0,5,10 \\
\text { and } 20 \mu \mathrm{M}\end{array}$ & $\begin{array}{l}\text { FAK, Sp-1, ADEM10, } \\
\text { calmodulin, EPHB2, } \\
\text { HDAC4, SEPP1, CD24, } \\
\text { and E-cadherin }\end{array}$ & $\begin{array}{l}\text { In vitro, } \\
\text { In vivo }\end{array}$ & $\begin{array}{l}\text { HCT-116, HT-29, } \\
\text { HCT-15, HCC-2998, } \\
\text { Colo205, Km-12, } \\
\text { and SW-620 }\end{array}$ & - & $\begin{array}{l}\text { - Suppressed metastasis via } \\
\text { Sp-1, FAK inhibition, and } \\
\text { E-Cadherin upregulation }\end{array}$ & $\begin{array}{l}\text { Chen et al. } \\
(2013)\end{array}$ \\
\hline Curcumin & $5-30 \mu \mathrm{M}$ & $\mathrm{miR}-21$ & In vitro & Rko and HCT116 & - & $\begin{array}{l}\text { - Inhibited invasion and } \\
\text { metastasis through regulation } \\
\text { miR-21 expression }\end{array}$ & $\begin{array}{l}\text { Mudduluru et al. } \\
\text { (2011) }\end{array}$ \\
\hline F36 and curcumin & $\begin{array}{l}10 \mu \mathrm{M} \\
\text { curcumin } 1,3 \text {, } \\
\text { and } 10 \mu \mathrm{M} \text { F36 }\end{array}$ & $\begin{array}{l}\text { CDX2, caspase-3, } \\
\text { PARP, cleaved PARP, } \\
\text { p-elF2a, CHOP, cyclin } \\
\text { D1, SERCA2, ATF4, } \\
p \text {-JNK, p-ERK, p-p38, } \\
p \text {-AKT, SI, and } \beta \text {-actin }\end{array}$ & $\begin{array}{l}\text { In vitro, } \\
\text { In vivo }\end{array}$ & $\begin{array}{l}\text { SW480, SW620, } \\
\text { HCT116, Caco2, } \\
\text { HT-29, and HT- } \\
29 \text { gal }\end{array}$ & 8 & $\begin{array}{l}\text { - F36 exhibited more potent } \\
\text { inhibitory effect in colorectal } \\
\text { cancer cells than curcumin } \\
\text { through inhibiting SERCA2 } \\
\text { expression }\end{array}$ & Fan et al. (2014) \\
\hline Curcumin & $5 \mu \mathrm{M}$ & $\begin{array}{l}\beta 1 \text {-integrin, ICAM-1, } \\
\text { TGF- } \beta 3, p-S m a d 2, \\
\text { cyclin D1, Ki-67, } \\
\text { vimentin, NF-кB, MMP- } \\
\text { 13, CD133, CD44, } \\
\text { ALDH1, E-cadherin, } \\
\beta \text {-actin, MMP-1, and } \\
\text { MMP-9 }\end{array}$ & In vitro & HCT116and MRC-5 & - & $\begin{array}{l}\text { - Modulation of crosstalk } \\
\text { between colon cancer stem } \\
\text { cells and stromal fibroblasts by } \\
\text { curcumin could be a potential } \\
\text { therapy for CRC and suppress } \\
\text { metastasis }\end{array}$ & $\begin{array}{l}\text { Buhrmann et al. } \\
\text { (2014) }\end{array}$ \\
\hline Curcumin & $\begin{array}{l}5,10,20, \text { and } \\
40 \mu \mathrm{mol} / \mathrm{L}\end{array}$ & $\begin{array}{l}\text { NKD2, CXCR4, } \\
\text { E-cadherin, Wnt } \\
\text { signaling, } \beta \text {-catenin, } \\
\beta \text {-actin, axin, and TCF4 }\end{array}$ & In vitro & SW620 & - & $\begin{array}{l}\text { - Inhibits tumor } \\
\text { epithelial-mesenchymal } \\
\text { transition by downregulating the } \\
\text { Wnt signaling pathway and } \\
\text { upregulating NKD2 expression }\end{array}$ & $\begin{array}{l}\text { Zhang et al. } \\
(2016)\end{array}$ \\
\hline Curcumin & $\begin{array}{l}0.1,1,5,10 \\
\text { and } 20 \mu \mathrm{M}\end{array}$ & CXCR4, MMP-9, NF-кB & In vitro & HCT116, HCT116R & - & $\begin{array}{l}\text { - Curcumin potentiates and } \\
\text { chemosensitizes } \\
\text { HCT116R cells to 5-FU-based } \\
\text { chemotherapy }\end{array}$ & $\begin{array}{l}\text { Shakibaei et al. } \\
\text { (2015) }\end{array}$ \\
\hline Curcumin & $\begin{array}{l}10,20 \\
\text { and } 50 \mu \mathrm{M}\end{array}$ & $\begin{array}{l}\text { Fatty acid synthase and } \\
\text { histone } \mathrm{H} 4\end{array}$ & In vitro & SW480 and SW620 & - & - Antimetastatic effect & Lee et al. (2015b) \\
\hline $\begin{array}{l}\text { Difluorinated- } \\
\text { curcumin (CDF) }\end{array}$ & $100 \mathrm{nM}$ & $\begin{array}{l}\text { miR-21, PTEN, Akt, } \\
p \text {-Akt, and } \beta \text {-actin }\end{array}$ & In vitro & $\begin{array}{l}\text { HCT116, HT-29, } \\
\text { and SW620 }\end{array}$ & - & $\begin{array}{l}\text { - Inhibit the growth of metastatic } \\
\text { colon cancer cells through } \\
\text { normalization of miR-21-PTEN- } \\
\text { Akt pathway }\end{array}$ & Roy (2013) \\
\hline Curcumin & $0-50 \mu \mathrm{M}$ & $\begin{array}{l}\text { NF- } \kappa B, ~ u P A, \text { and } \\
\text { MMP-9 }\end{array}$ & In vitro & SW480 and LoVo & - & $\begin{array}{l}\text { - Suppressed cancer cell } \\
\text { invasion via AMPK-induced } \\
\text { inhibition of NF-кB, uPA } \\
\text { activator, and MMP9 }\end{array}$ & $\begin{array}{l}\text { Tong et al. } \\
(2016)\end{array}$ \\
\hline
\end{tabular}


TABLE 3 | (Continued) Curcumin-induced antimetastatic effects against colorectal cancer.

\begin{tabular}{|c|c|c|c|c|c|c|c|}
\hline Type of curcumin & Dose & Target & Model & Cell line & $\begin{array}{l}\text { Sample } \\
\text { size }\end{array}$ & Results & Ref. \\
\hline Curcumin & $\begin{array}{l}5,10,20 \\
\text { and } 40 \mu \mathrm{M}\end{array}$ & MMP-9 and E-cadherin & In vitro & HCT-116 & - & $\begin{array}{l}\text { - Synergism from the } \\
\text { combination of ulinastatin and } \\
\text { curcumin showed greater } \\
\text { inhibition against colorectal } \\
\text { cancer liver metastases through } \\
\text { modulating matrix } \\
\text { metalloproteinase-9 and } \\
\text { E-cadherin expression }\end{array}$ & $\begin{array}{l}\text { Shen et al. } \\
(2014)\end{array}$ \\
\hline Curcumin & $\begin{array}{l}10 \text { and } 50 \mu \mathrm{M} \\
\text { in vitro and } \\
1 \mathrm{~g} / \mathrm{kg} \text { in vivo }\end{array}$ & $\begin{array}{l}\text { NF-kB, cyclin D1, c-myc, } \\
\text { bcl-2, Bcl-xL, clAP-1, } \\
\text { COX-2, ICAM-1, MMP- } \\
\text { 9, CXCR4, and VEGF }\end{array}$ & $\begin{array}{l}\text { In vitro, } \\
\text { In vivo }\end{array}$ & НCT 116 & 8 & $\begin{array}{l}\text { - Sensitized cancer cells to } \\
\text { capecitabine by modulation of } \\
\text { cyclin D1, COX-2, MMP-9, } \\
\text { VEGF, and CXCR4 expression }\end{array}$ & $\begin{array}{l}\text { Kunnumakkara } \\
\text { et al. (2009) }\end{array}$ \\
\hline $\begin{array}{l}\text { Curcumin-loaded } \\
\text { polymeric micelles, } \\
\text { thermosensitive } \\
\text { hydrogel system, and } \\
\text { its free form }\end{array}$ & $\begin{array}{l}50 \mathrm{mg} / \mathrm{kg} \text { in } \\
\text { vivo/20 and } \\
200 \mu \mathrm{g} / \mathrm{ml} \\
\text { in vitro }\end{array}$ & NA & $\begin{array}{l}\text { In vitro, } \\
\text { In vivo }\end{array}$ & СТ26 & 10 & $\begin{array}{l}\text { - Inhibited tumor growth and } \\
\text { metastasis, and prolonged } \\
\text { survival of tumor-bearing mice }\end{array}$ & $\begin{array}{l}\text { Zhang et al. } \\
(2015)\end{array}$ \\
\hline Curcumin & $\begin{array}{l}10,20 \\
\text { and } 50 \mu \mathrm{M}\end{array}$ & $\begin{array}{l}\text { Fatty acid synthase and } \\
\text { histone } \mathrm{H} 4\end{array}$ & In vitro & SW480 and SW620 & - & $\begin{array}{l}\text { - Antimetastatic components } \\
\text { revealed by the current } \\
\text { proteomic analysis }\end{array}$ & Lee et al. (2014) \\
\hline $\begin{array}{l}\text { Dendrosomal } \\
\text { curcumin }\end{array}$ & $0-30 \mu \mathrm{M}$ & $\begin{array}{l}\text { Hef1-1, Zeb1, Claudin 1, } \\
\text { and Gapdh }\end{array}$ & In vitro & SW480 & - & $\begin{array}{l}\text { - Inhibited metastatic potential of } \\
\text { cancer cells through } \\
\text { downregulation of Claudin1, } \\
\text { Zeb1, and Hef1-1 gene } \\
\text { expression }\end{array}$ & $\begin{array}{l}\text { Esmatabadi et al. } \\
\text { (2015) }\end{array}$ \\
\hline Curcumin & 5 or $25 \mu \mathrm{M}$ & $\begin{array}{l}\text { IL-8, NF-kB, ERK, and } \\
\text { AP-1 }\end{array}$ & In vitro & HCT116, HT29 & - & $\begin{array}{l}\text { - Inhibited neurotensin- } \\
\text { mediated interleukin-8 } \\
\text { production and migration }\end{array}$ & $\begin{array}{l}\text { Wang et al. } \\
(2006)\end{array}$ \\
\hline FLLL32 and curcumin & $\begin{array}{l}10,25 \\
\text { and } 50 \mu \mathrm{M}\end{array}$ & $\begin{array}{l}\text { Bcl-xL, caspase-3, } \\
\text { survivin, and STAT3 }\end{array}$ & In vitro & $\begin{array}{l}\text { DLD-1, HCT-116, } \\
\text { and SW480 }\end{array}$ & - & $\begin{array}{l}\text { - Inhibited cell viability and } \\
\text { induced apoptosis through } \\
\text { suppression of STAT3 } \\
\text { phosphorylation }\end{array}$ & Lin et al. (2011) \\
\hline $\begin{array}{l}\text { Curcumin nanofibrous } \\
\text { microspheres }\end{array}$ & $2 \mu \mathrm{g} / \mathrm{ml}$ & NA & $\begin{array}{l}\text { In vitro, } \\
\text { In vivo }\end{array}$ & CT26 and L929 & 6 & $\begin{array}{l}\text { - Increased induction of } \\
\text { apoptosis in tumor cells and } \\
\text { inhibition of tumor angiogenesis } \\
\text { for treating abdominal } \\
\text { metastases }\end{array}$ & Fan et al. (2016) \\
\hline CDF & $100 \mathrm{nM}$ & miR-34a,b,c & In vitro & $\begin{array}{l}\text { SW620, } \\
\text { HCT116CR, } \\
\text { HCT116p53 }{ }^{-/-} \text {, and } \\
\text { HCT116wt }\end{array}$ & - & $\begin{array}{l}\text { - Re-expression of miR-34a and } \\
\text { miR-34c, which was consistent } \\
\text { with inhibition of cell growth }\end{array}$ & Roy et al. (2012) \\
\hline Curcumin & $\begin{array}{l}0,1,3 \\
\text { and } 10 \mu \mathrm{M}\end{array}$ & Bcl-2 and miR-497 & In vitro & $\begin{array}{l}\text { HCT8 and } \\
\text { HCT8/DDP }\end{array}$ & - & $\begin{array}{l}\text { - Restrained proliferation and } \\
\text { facilitated apoptosis }\end{array}$ & $\begin{array}{l}\text { Zheng et al. } \\
(2020)\end{array}$ \\
\hline Curcumin & $25 \mu \mathrm{M}$ & $\begin{array}{l}\text { hsp27, hsp } 70, \beta \text {-actin, } \\
\text { cytochrome c, Smac, } \\
\text { AIF, caspase-3, -8, -9, } \\
\text { PARP, and DFF45 }\end{array}$ & In vitro & SW480 & - & $\begin{array}{l}\text { - Induced apoptosis via } \\
\text { activation of caspases } 3 \text { and } 9 \\
\text { which was inhibited by hsp70 }\end{array}$ & $\begin{array}{l}\text { Rashmi et al. } \\
(2004)\end{array}$ \\
\hline $\begin{array}{l}\text { Palladium complexes } \\
\text { with 1,7-bis(2- } \\
\text { methoxyphenyl) } \\
\text { hepta-1,6-diene-3,5- } \\
\text { dione }\end{array}$ & NA & CD133, DLD-1 & In vitro & HТ-29 & - & $\begin{array}{l}\text { - Exhibited antitumor effect and } \\
\text { the hepatic metastasis of a } \\
\text { colorectal carcinoma }\end{array}$ & $\begin{array}{l}\text { Fischer-Fodor } \\
\text { et al. (2017) }\end{array}$ \\
\hline
\end{tabular}

(Martin et al., 2005), head and neck cancer (Yang et al., 2008). Emerging evidence has shown that E-cadherin downregulation is reversely connected with general survival in patients with different epithelial tumors (Richmond et al., 1997; Zhou et al., 2002; Faleiro-Rodrigues et al., 2004; Tseng et al., 2010; Huber et al., 2011). For example, Fan et al. reported expression levels of Snail and Twist were upregulated. In contrast, E-cadherin expression level was downregulated in oral squamous cell carcinoma (OSCC) patients. Besides, E-cadherin lower expression has been introduced to be an individual prognostic marker in patients with OSCC (Fan et al., 2013).

Lee et al. evaluated curcumin antiinvasive properties on the level of MMPs expression and EMT modulators in OSCC SCC-25 cell line (Lee et al., 2015a). Their results demonstrated that MMP- 
2 and MMP-9 expression significantly decreased, and hence, invasiveness of oral cancer cells was inhibited after curcumin treatment. Curcumin strongly regulated the expression level of EMT-related factors, including Twist, Snail, and E-cadherin. Besides, curcumin treatment upregulated the p53 expression level, which has been demonstrated to be a crucial factor for repressing EMT. Throughout, it can be said that curcumin has critical functions for preventing cancer development, invasion, and metastasis in oral cancer (Lee et al., 2015a).

Epidermal growth factor receptor (EGFR) is a transmembrane protein with $170-\mathrm{kDa}$ molecular weight, and ErbB family member belongs to receptor tyrosine kinases. It has an extracellular ligandbinding, a transmembrane, and an intracellular domain, which have been reported to be associated with tyrosine kinase activity. Binding of ErbB to epidermal growth factor (EGF) as its primary ligand resulted in the EGFR-mediated formation of heterodimers or homodimers with other ErbB protein family members, including ErbB2, ErbB3, and ErbB4. This causes autophosphorylation, which led to the downstream signaling activation, including MAPK/Ras/Raf/ERK, JAK2/STAT3, and PI3K/Akt/mTOR pathways. These signaling pathways have crucial roles in regulating cancer cell proliferation, differentiation, invasion, and migration (Yarden and Sliwkowski, 2001). Studies have shown that activity and upregulation of EGFR are strongly related to increased tumor invasiveness, multiplication, and metastasis (Doumiati et al., 2012; Lin et al., 2014a). Poor prognosis and inadequate responses to chemotherapy have been observed in positive pEGFR tumors (Aquino et al., 2012). Hence, EGFR has been introduced as an essential anticancer drug target (Rabinowits and Haddad, 2012). Classic EGFR inhibitors have been divided into two major categories, including anti-EGFRs monoclonal antibodies and cetuximab, panitumumab, and trastuzumab are anti-EGFRs monoclonal antibodies, while gefitinib, erlotinib, and lapatinib are categorized as tyrosine kinases inhibitors. Currently, the mentioned drugs are used for the treatment of some epithelium-originated carcinomas, such as colorectal (Soeda et al., 2014), head and neck (Maseki et al., 2013), lung (Sgambato et al., 2014), and breast cancer (Nechushtan et al., 2014). Moreover, because of their extended side effects and chemoresistance, the application of these inhibitors has been very limited in treating most patients with cancer.

Through decreasing Egr-1 trans-activation activities, it has been shown that curcumin inhibited the EGFR-mediated growth of human colon cancer cells (Chen et al., 2006). Furthermore, via repressing EGFR expression, cell apoptosis was significantly promoted in breast cancer cells after curcumin treatment (Sun et al., 2012).

Zhen et al. studied the effectiveness of curcumin on invasion and proliferation in SCC-25 cell lines (Zhen et al., 2014). Based on their results, considerable inhibitory effects were observed from curcumin on the SCC-25 cells' proliferation. Furthermore, curcumin caused the arrest of the cell cycle in the G2/M phase in a dose-dependent manner. Curcumin downregulated the MMP-2, MMP-9, uPA, and UPAR expression, which led to the inhibited invasion of SCC-25 cells. Curcumin downregulated the MMP-9, MMP-2, uPAR, and uPA expression, which led to the inhibited invasion of SCC- 25 cells. It has also been revealed that curcumin regulated Akt, ERK1/2, and STAT3 as downstream signaling targets of $p$-EGFR and EGFR. Besides, as the most important finding of their study, EGF-triggered EGFR phosphorylation and EGF-mediated invasion of SCC-25 cells were suppressed after treatment with curcumin (Zhen et al., 2014).

In various cancer types, hepatocyte growth factor (HGF) and c-Met, its receptor, have been explained to be implicated in the EMT program (Huang et al., 2019). Remarkably, emerging evidence has shown that the HGF/c-Met signaling pathway activation promoted cancer cell migration and invasiveness. Chemopreventive and antitumoral activities of Curcumin have been comprehensively investigated in colorectal cancer (Ismail and Othman, 2019; Wong et al., 2019). Moreover, curcumin has been introduced to be a prominent EMT suppressor in various cancers (Jiao et al., 2016; Liang et al., 2017; Wang et al., 2017; Bahrami et al., 2019b).

In a study, Ohnishi et al. studied the potential impacts of curcumin on HGF-induced EMT in OSCC (Ohnishi et al., 2020). They reported that via activating HGF receptor c-Met, and downstream ERK pathway in HSC4 and Ca9-22 OSCC cell lines, the HGF signaling pathway induced EMT process. Furthermore, via repressing c-Met, HGF-mediated EMT and cell motility were inhibited by curcumin treatment in HSC-4 and Ca9-22 cells. Through downregulating the expression levels of phosphorylated c-Met, and ERK, curcumin effectively inhibited the HGF-triggered upregulation of vimentin. Taking everything into account, the findings of the reviewed investigation demonstrated that possibly by inhibiting c-Met expression, curcumin has pivotal roles in reversed regulating of HGF-induced EMT in oral cancer cells (Ohnishi et al., 2020). Table 4 lists various studies on antimetastatic effects in oral cancer.

\section{Regulation of Metastasis in Esophageal Cancer by Curcumin}

As an important member of the CXC subfamily, stromal cellderived factor 1a (SDF-1a) interacts with the C-X-C chemokine receptor type 4 (CXCR4), seven-transmembrane $\mathrm{G}$ proteincoupled receptor (7TMGPCR). It is also a principal agent in the induction of metastasis and invasion in cancer cells (Vandercappellen et al., 2008). Various in vivo studies have shown that SDF-1a is a key agent for triggering migration and metastasis in breast cancer cells (Müller et al., 2001). Moreover, suppression of CXCR4 gene expression mediated by Short hairpin RNA (shRNA) significantly inhibited cell proliferation of esophageal carcinoma (EC). Upregulation of CXCR4 has been reported to be related to poor prognosis, poor clinical outcomes, and raised metastatic features in EC cells (Kaifi et al., 2005).

Lipid rafts are plasma membrane firmly packed microdomains that consist of dynamic assemblies of cholesterol, glycosphingolipid, and proteins. The rafts can affect signal transduction via the recruitment of membrane-associated protein kinases (Zajchowski and Robbins, 2002). The interaction between the growth factors and their receptors 
TABLE 4 | Efficacy of curcumin for triggering metastasis in oral cancer.

\begin{tabular}{|c|c|c|c|c|c|c|c|}
\hline $\begin{array}{l}\text { Type of } \\
\text { curcumin }\end{array}$ & Dose & Target & Model & Cell line & $\begin{array}{l}\text { Sample } \\
\text { size }\end{array}$ & Results & Ref. \\
\hline Curcumin & $0-15 \mu \mathrm{M}$ & $\begin{array}{l}\text { p53, Snail, Twist, } \\
\text { E-cadherin, MMP-2, } \\
\text { MMP-9 }\end{array}$ & In vitro & SCC25 & - & $\begin{array}{l}\text { - Inhibited invasiveness and } \\
\text { epithelial-mesenchymal transition through } \\
\text { reducing MMP 2, } 9 \text { and modulating p53-E- } \\
\text { cadherin pathway }\end{array}$ & $\begin{array}{l}\text { Lee et al. } \\
(2015 a)\end{array}$ \\
\hline Curcumin & $\begin{array}{l}0,10,20,40 \\
80 \mu \mathrm{mol} / \mathrm{L}\end{array}$ & $\begin{array}{l}\text { EGFR, P-EGFR, Akt, } \\
\text { ERK1/2, STAT3, MMP- } \\
\text { 2, MMP-9, UPA, and } \\
\text { UPAR }\end{array}$ & In vitro & SCC-25 & - & $\begin{array}{l}\text { - Inhibited cell proliferation and invasion via } \\
\text { EGFR signaling pathways }\end{array}$ & $\begin{array}{l}\text { Zhen et al. } \\
\text { (2014) }\end{array}$ \\
\hline Curcumin & $\begin{array}{l}0,5,10,20,30,60 \\
\text { and } 100 \mu \mathrm{mol} / \mathrm{L}\end{array}$ & $\begin{array}{l}\text { cdc27, EGFR substrate } \\
\text { 15, and PPAR- } \alpha\end{array}$ & In vitro & SCC-4 & - & - Antiproliferative and antimetastatic effects & $\begin{array}{l}\text { Chen et al. } \\
\text { (2011) }\end{array}$ \\
\hline Curcumin & $\begin{array}{l}2,5,10,20,30,40, \\
\text { and } 50 \mu \mathrm{M} \text { in vitro and } \\
70 \mathrm{mg} / \mathrm{kg} \text { in vivo }\end{array}$ & NA & $\begin{array}{l}\text { In vitro, } \\
\text { In vivo }\end{array}$ & $\begin{array}{l}\text { HACAT, } \\
\text { CAL27, } \\
\text { SCC25, and } \\
\text { NIH-3T3 }\end{array}$ & NA & - Inhibited cell migration & $\begin{array}{l}\text { de Campos } \\
\text { et al. (2017) }\end{array}$ \\
\hline Curcumin & $15 \mu \mathrm{M}$ & $\begin{array}{l}\text { ERK, c-met, E-cadherin, } \\
\text { vimentin, pro-MMP2, } \\
\text { pro-MMP9 }\end{array}$ & In vitro & $\begin{array}{l}\text { HSC4 and } \\
\text { Ca9-22 }\end{array}$ & - & $\begin{array}{l}\text { - Inhibits epithelial-mesenchymal transition } \\
\text { in cancer cells via c-Met blockade }\end{array}$ & $\begin{array}{l}\text { Ohnishi } \\
\text { et al. (2020) }\end{array}$ \\
\hline Curcumin & $20 \mu \mathrm{M}$ & Snail, $\beta$-actin & In vitro & $\begin{array}{l}\text { OECM-1, } \\
\text { HOKs }\end{array}$ & - & $\begin{array}{l}\text { - Reduced tumors differentiation and } \\
\text { metastasis through downregulation of Snail } \\
\text { expression }\end{array}$ & $\begin{array}{l}\text { Lee et al. } \\
(2013)\end{array}$ \\
\hline Curcumin & 0-100 mmol/L & MMP-2, MMP-9 & In vitro & Tca8113 & - & $\begin{array}{l}\text { - Suppressed invasion and migration by } \\
\text { reducing the activities of MMP-2 and } \\
\text { MMP-9 }\end{array}$ & $\begin{array}{l}\text { Wang et al. } \\
\text { (2008) }\end{array}$ \\
\hline
\end{tabular}

plays a critical role in specific adapter proteins and protein kinases translocation to lipid rafts. It provides essential signals for the regulation of cell proliferation (Pike, 2005). Numerous authors demonstrate that the CXCR4 connection with lipid rafts is involved in effective signaling processes (Chinni et al., 2008; Altenburg and Siddiqui, 2009). Ectopic expression of a CXCR4GFP fusion protein in CXCR4-deficient human hematopoietic progenitor cell lines showed that lipid rafts are crucial in the SDF1a-induced CXCR4 signaling and surface expression (van Buul et al., 2003).

The colocalization of Rho GTP-binding protein Racl and CXCR4 in lipid rafts resulted in increased activation of Rac1 GTPase. It also led to the sensitivity of hematopoietic cells to SDF-1a (Wysoczynski et al., 2005). SDF-1a/CXCR4 axismediated cell migration needs the activation of phosphatidylinositol 3- kinase (PI3K)/protein kinase B (Akt) in breast cancer cells (Lee et al., 2004). Numerous investigations demonstrated that hormones, growth factors, and cytokines stimulated the MMP-2 expression via nuclear factor-kappaB (NF-kB) activation (Han et al., 2001; Philip et al., 2004). NF-kB transcription factor constitutive activation in EC has been related to metastatic ability and chemotherapy resistance (Izzo et al., 2006). Besides, active Rac1 (GTP bound Rac1; GTP-Rac1) is required for collagen-mediated MMP-2 activation (Zhuge and $\mathrm{Xu}, 2001$ ).

Lin et al. investigated these features by evaluating the CXCR4 suppression effects along with a CXCR4-neutralizing antibody and the CXCR4-specific inhibitor AMD3100 treatments (Lin et al., 2014b). Curcumin prevents SDF-1 $\alpha$-mediated cell migration, cell surface localization of CXCR4 at lipid rafts, the activity of matrix metalloproteinase-2 (MMP-2) promoter, and also signaling of lipid raft-related ras-related C3 botulinum toxin substrate 1 (Rac1)/phosphatidylinositol 3-kinase (PI3K) p85a/ Akt. Furthermore, curcumin inhibits SDF-1a-mediated cell metastasis by knockdown of the signaling complex of Rac1PI3K at lipid rafts but did not abolish lipid raft generation. Researchers also explain that the decreasing lipid raft-related Racl activity by curcumin was the requirement for preventing cell surface localization of CXCR4 at lipid rafts, SDF-1a-mediated $\mathrm{PI} 3 \mathrm{~K} / \mathrm{Akt} / \mathrm{NF}-\mathrm{\kappa B}$ activation, cell invasion, and MMP-2 promoter activity. Overall, their findings displayed that curcumin hinders SDF-1 $\alpha$-mediated EC cell invasion by suppressing the lipid raft formation-related Rac1-PI3K-Akt signaling complex, MP-2 promoter activity, likely through the inhibition of Racl activity, and the cell surface localization of CXCR4 with lipid rafts (Lin et al., 2014b).

\section{CONCLUSION}

For centuries, curcumin has been widely used as a dietary spice, and contemporary research studies have confirmed its efficacy in cancer therapy. Anticancer effects are the most pivotal properties of curcumin, which affect the different stages of cancer progression, including cancer cell formation, proliferation, and tumor invasion. According to extensive research, curcumin can suppress metastasis in GI cancers via regulating various signaling pathways. Curcumin has a crucial function in metastasis prevention by several mechanisms, including preventing transcription factors as well as their signaling pathways (e.g., NF- $\kappa$ B, STAT3, AP-1), multiple proteases (e.g., MMPs, uPA), inflammatory cytokines (e.g., CXCL1, IL-6, CXCL2, IL-8), modulation of miRNAs (e.g., miR181b, miR21), multiple protein kinases (e.g., FAK, MAPKs), and heat shock proteins 
(HLJ1). According to research, curcumin treatment leads to significant elevation in metastatic tumor cross-sectional volume (70\%) and zone (46\%). Curcumin may enhance LLC's metastatic growth in mice by elevating the concentration of VEGF, angiogenic factors, monocyte chemotactic protein-1 (MCP-1), and IL-1 $\beta$.

In addition to the possible pharmaceutical effects of curcumin, the safety and relevant therapeutic dose should also be established, given reports on the side effects of curcumin in cancer therapy. Future clinical and preclinical investigations on anti-metastasis properties of curcumin should be designed in a way that indicates the safety and effectiveness of curcumin in inhibiting cancer metastasis.

It has been found that curcumin nanoparticles improve their anticancer properties via cancer cellular uptake enhancement, targeted zone internalization, and high bioavailability. Polymeric nanoparticles, polymeric micelles, and liposomes are the regular nano-carriers exploited for curcumin encapsulation. More efforts are needed to

\section{REFERENCES}

Abe, Y., Hashimoto, S., and Horie, T. (1999). Curcumin Inhibition of Inflammatory Cytokine Production by Human Peripheral Blood Monocytes and Alveolar Macrophages. Pharmacol. Res. 39 (1), 41-47. doi:10.1006/ phrs.1998.0404

Adachi, Y., Lee, C. T., Coffee, K., Yamagata, N., Ohm, J. E., Park, K. H., et al. (2002). Effects of Genetic Blockade of the Insulin-like Growth Factor Receptor in Human colon Cancer Cell Lines. Gastroenterology 123 (4), 1191-1204. doi:10.1053/gast.2002.36023

Aggarwal, B. B., Surh, Y.-J., and Shishodia, S. (2007). The Molecular Targets and Therapeutic Uses of Curcumin in Health and Disease, 595. Springer Science \& Business Media.

Aggarwal, S., Takada, Y., Singh, S., Myers, J. N., and Aggarwal, B. B. (2004). Inhibition of Growth and Survival of Human Head and Neck Squamous Cell Carcinoma Cells by Curcumin via Modulation of Nuclear Factor-?B Signaling. Int. J. Cancer 111 (5), 679-692. doi:10.1002/ijc.20333

Altenburg, J. D., and Siddiqui, R. A. (2009). Omega-3 Polyunsaturated Fatty Acids Down-Modulate CXCR4 Expression and Function in MDA-MB-231 Breast Cancer Cells. Mol. Cancer Res. 7 (7), 1013-1020. doi:10.1158/1541-7786.mcr08-0385

Anand, P., Kunnumakkara, A. B., Newman, R. A., and Aggarwal, B. B. (2007). Bioavailability of Curcumin: Problems and Promises. Mol. Pharmaceutics 4 (6), 807-818. doi:10.1021/mp700113r

Aquino, G., Pannone, G., Santoro, A., Liguori, G., Franco, R., Serpico, R., et al. (2012). pEGFR-Tyr 845 Expression as Prognostic Factors in Oral Squamous Cell Carcinoma. Cancer Biol. Ther. 13 (11), 967-977. doi:10.4161/cbt.20991

Arya, G., Das, M., and Sahoo, S. K. (2018). Evaluation of Curcumin Loaded Chitosan/ PEG Blended PLGA Nanoparticles for Effective Treatment of Pancreatic Cancer. Biomed. Pharmacother. 102, 555-566. doi:10.1016/j.biopha.2018.03.101

Ashrafizadeh, M., Zarrabi, A., Hashemipour, M., Vosough, M., Najafi, M., Shahinozzaman, M., et al. (2020). Sensing the Scent of Death: Modulation of microRNAs by Curcumin in Gastrointestinal Cancers. Pharmacol. Res. 160, 105199. doi:10.1016/j.phrs.2020.105199

Axelrad, J. E., Lichtiger, S., and Yajnik, V. (2016). Inflammatory Bowel Disease and Cancer: The Role of Inflammation, Immunosuppression, and Cancer Treatment. Wjg 22 (20), 4794-4801. doi:10.3748/wjg.v22.i20.4794

Bachmeier, B. E., Nerlich, A. G., Lichtinghagen, R., and Sommerhoff, C. P. (2001). Matrix Metalloproteinases (MMPs) in Breast Cancer Cell Lines of Different Tumorigenicity. Anticancer Res. 21 (6a), 3821-3828.

Bachmeier, B. E., Boukamp, P., Lichtinghagen, R., Fusenig, N. E., Fink, E., et al. (2000). Matrix Metalloproteinases-2,-3,-7,-9 And-10, but Not MMP-11, Are improve curcumin nanoparticles for targeted therapy of cancer cells (e.g., nanoparticle coating with peptides/ antibodies that bind to upregulated receptors on the cancer cells' surface) in the future.

\section{AUTHOR CONTRIBUTIONS}

$\mathrm{HM}$ involved in the conception, design, statistical analysis and drafting of the manuscript. AD, MF, EA, HK, MMT, NZ, SAA, SMS, GB, MA and HK contributed to data collection and manuscript drafting. All authors approved the final version for submission.

\section{FUNDING}

MA was supported in part by the National Institute of Environmental Health Sciences (NIEHS) R01ES07331.
Differentially Expressed in normal, Benign Tumorigenic and Malignant Human Keratinocyte Cell Lines. Biol. Chem. 381 (5-6), 497-507. doi: $10.1515 / b c .2000 .064$

Bachmeier, B. E., Iancu, C. M., Killian, P. H., Kronski, E., Mirisola, V., Angelini, G., et al. (2009). Overexpression of the ATP Binding Cassette Gene ABCA1 Determines Resistance to Curcumin in M14 Melanoma Cells. Mol. Cancer 8, 129. doi:10.1186/1476-4598-8-129

Bachmeier, B. E., Nerlich, A. G., Boukamp, P., Lichtinghagen, R., Tschesche, H., Fritz, H., et al. (2000). Human Keratinocyte Cell Lines Differ in the Expression of the Collagenolytic Matrix Metalloproteinases-1,-8, and -13 and of TIMP-1. Biol. Chem. 381 (5-6), 509-516. doi:10.1515/bc.2000.065

Bachmeier, B., et al. (2007). The Chemopreventive Polyphenol Curcumin Prevents Hematogenous Breast Cancer Metastases in Immunodeficient Mice. Cell Physiol Biochem 19 (1-4), 137-152. doi:10.1159/000099202

Bahrami, A., Fereidouni, M., Pirro, M., Bianconi, V., and Sahebkar, A. (2019). Modulation of Regulatory T Cells by Natural Products in Cancer. Cancer Lett. 459, 72-85. doi:10.1016/j.canlet.2019.06.001

Bahrami, A., Majeed, M., and Sahebkar, A. (2019). Curcumin: a Potent Agent to Reverse Epithelial-To-Mesenchymal Transition. Cell Oncol. 42 (4), 405-421. doi:10.1007/s13402-019-00442-2

Bakhoum, S. F., Ngo, B., Laughney, A. M., Cavallo, J.-A., Murphy, C. J., Ly, P., et al. (2018). Chromosomal Instability Drives Metastasis through a Cytosolic DNA Response. Nature 553 (7689), 467-472. doi:10.1038/nature25432

Banerii, A., Chakrabarti, J., Mitra, A., and Chatterjee, A. (2004). Effect of Curcumin on Gelatinase A (MMP-2) Activity in B16F10 Melanoma Cells. Cancer Lett. 211 (2), 235-242. doi:10.1016/j.canlet.2004.02.007

Bao, B., Azmi, A. S., Ali, S., Zaiem, F., Sarkar, F. H., et al. (2012). Hypoxia-induced Aggressiveness of Pancreatic Cancer Cells Is Due to Increased Expression of VEGF, IL-6 and miR-21, Which Can Be Attenuated by CDF Treatment. PLoS One 7 (12), e50165. doi:10.1371/journal.pone.0050165

Bielenberg, D. R., and Zetter, B. R. (2015). The Contribution of Angiogenesis to the Process of Metastasis. Cancer J. 21 (4), 267-273. doi:10.1097/ ppo. 0000000000000138

Bisht, S., Mizuma, M., Feldmann, G., Ottenhof, N. A., Hong, S.-M., Pramanik, D., et al. (2010). Systemic Administration of Polymeric Nanoparticle-Encapsulated Curcumin (NanoCurc) Blocks Tumor Growth and Metastases in Preclinical Models of Pancreatic Cancer. Mol. Cancer Ther. 9 (8), 2255-2264. doi:10.1158/ 1535-7163.mct-10-0172

Bond, M., et al. (2001). Inhibition of Transcription Factor NF-Kb Reduces Matrix Metalloproteinase-1, -3 and -9 Production by Vascular Smooth Muscle Cells. Cardiovasc. Res. 50 (3), 556-565. doi:10.1016/s0008-6363(01)00220-6

Bos, J. L. (1989). Ras Oncogenes in Human Cancer: a Review. Cancer Res. 49 (17), $4682-4689$. 
Brooks, S. A., Lomax-Browne, H. J., Carter, T. M., Kinch, C. E., and Hall, D. M. S. (2010). Molecular Interactions in Cancer Cell Metastasis. Acta Histochem. 112 (1), 3-25. doi:10.1016/j.acthis.2008.11.022

Buhrmann, C., Kraehe, P., Lueders, C., Shayan, P., Goel, A., Shakibaei, M., et al. (2014). Curcumin Suppresses Crosstalk between colon Cancer Stem Cells and Stromal Fibroblasts in the Tumor Microenvironment: Potential Role of EMT. PLoS One 9 (9), e107514. doi:10.1371/journal.pone.0107514

Buhrmann, C., Popper, B., Kunnumakkara, A. B., Aggarwal, B. B., Shakibaei, M., et al. (2019). Evidence that Calebin A, a Component of Curcuma Longa Suppresses NF-B Mediated Proliferation, Invasion and Metastasis of Human Colorectal Cancer Induced by TNF- $\beta$ (Lymphotoxin). Nutrients 11 (12). doi:10.3390/nu11122904

Calibasi-Kocal, G., Pakdemirli, A., Bayrak, S., Ozupek, N. M., Sever, T., Basbinar, Y., et al. (2019). Curcumin Effects on Cell Proliferation, Angiogenesis and Metastasis in Colorectal Cancer. J. Buon 24 (4), 1482-1487.

Campbell, P. M., and Der, C. J. (2004). Oncogenic Ras and its Role in Tumor Cell Invasion and Metastasis. Semin. Cancer Biol. 14 (2), 105-114. doi:10.1016/ j.semcancer.2003.09.015

Cao, L., Liu, J., Zhang, L., Xiao, X., and Li, W. (2016). Curcumin Inhibits H2O2Induced Invasion and Migration of Human Pancreatic Cancer via Suppression of the ERK/NF-kB Pathway. Oncol. Rep. 36 (4), 2245-2251. doi:10.3892/ or.2016.5044

Cao, L., Xiao, X., Lei, J., Duan, W., Ma, Q., and Li, W. (2016). Curcumin Inhibits Hypoxia-Induced Epithelial-Mesenchymal Transition in Pancreatic Cancer Cells via Suppression of the Hedgehog Signaling Pathway. Oncol. Rep. 35 (6), 3728-3734. doi:10.3892/or.2016.4709

Chang, J., and Erler, J. (2014). Hypoxia-mediated Metastasis. Adv. Exp. Med. Biol. 772, 55-81. doi:10.1007/978-1-4614-5915-6_3

Chen, A., Xu, J., and Johnson, A. C. (2006). Curcumin Inhibits Human colon Cancer Cell Growth by Suppressing Gene Expression of Epidermal Growth Factor Receptor through Reducing the Activity of the Transcription Factor Egr1. Oncogene 25 (2), 278-287. doi:10.1038/sj.onc.1209019

Chen, C. C., Sureshbabul, M., Chen, H. W., Lin, Y. S., Lee, J. Y., Hong, Q. S., et al. (2013). Curcumin Suppresses Metastasis via Sp-1, FAK Inhibition, and E-Cadherin Upregulation in Colorectal Cancer. Evid. Based Complement. Alternat Med. 2013, 541695. doi:10.1155/2013/541695

Chen, J. W., Tang, Y. L., Liu, H., Zhu, Z. Y., Lü, D., Geng, N., et al. (2011). Antiproliferative and Anti-metastatic Effects of Curcumin on Oral Cancer Cells. Hua Xi Kou Qiang Yi Xue Za Zhi 29 (1), 83-86.

Chen, Q.-y., Zheng, Y., Jiao, D.-m., Chen, F.-y., Hu, H.-z., Wu, Y.-q., et al. (2014). Curcumin Inhibits Lung Cancer Cell Migration and Invasion through Racldependent Signaling Pathway. J. Nutr. Biochem. 25 (2), 177-185. doi:10.1016/ j.jnutbio.2013.10.004

Chen, W., Zou, P., Zhao, Z., Weng, Q., Chen, X., Ying, S., et al. (2016). Selective Killing of Gastric Cancer Cells by a Small Molecule via Targeting TrxR1 and ROS-Mediated ER Stress Activation. Oncotarget 7 (13), 16593-16609. doi:10.18632/oncotarget.7565

Cheung, K. J., and Ewald, A. J. (2016). A Collective Route to Metastasis: Seeding by Tumor Cell Clusters. Science 352 (6282), 167-169. doi:10.1126/science.aaf6546

Chinni, S. R., Yamamoto, H., Dong, Z., Sabbota, A., Bonfil, R. D., and Cher, M. L. (2008). CXCL12/CXCR4 Transactivates HER2 in Lipid Rafts of Prostate Cancer Cells and Promotes Growth of Metastatic Deposits in Bone. Mol. Cancer Res. 6 (3), 446-457. doi:10.1158/1541-7786.mcr-07-0117

Christofori, G. (2006). New Signals from the Invasive Front. Nature 441 (7092), 444-450. doi:10.1038/nature04872

Chung, H., Lee, S.-G., Kim, H., Hong, D., Chung, J., Stroncek, D., et al. (2009). Serum High Mobility Group Box-1 (HMGB1) Is Closely Associated with the Clinical and Pathologic Features of Gastric Cancer. J. Translational Med. 7, 38. doi:10.1186/1479-5876-7-38

Clark, A. G., and Vignjevic, D. M. (2015). Modes of Cancer Cell Invasion and the Role of the Microenvironment. Curr. Opin. Cel Biol. 36, 13-22. doi:10.1016/ j.ceb.2015.06.004

Cowin, P., Rowlands, T. M., and Hatsell, S. J. (2005). Cadherins and Catenins in Breast Cancer. Curr. Opin. Cel Biol. 17 (5), 499-508. doi:10.1016/j.ceb.2005.08.014

Craene, B. D., and Berx, G. (2013). Regulatory Networks Defining EMT during Cancer Initiation and Progression. Nat. Rev. Cancer 13 (2), 97-110. doi:10.1038/nrc3447
Da, W., Zhang, J., Zhang, R., and Zhu, J. (2019). Curcumin Inhibits the Lymphangiogenesis of Gastric Cancer Cells by Inhibiton of HMGB1/VEGFD Signaling. Int. J. Immunopathol Pharmacol. 33, 2058738419861600. doi: $10.1177 / 2058738419861600$

Da, W., Zhu, J., Wang, L., and Sun, Q. (2015). Curcumin Suppresses Lymphatic Vessel Density in an In Vivo Human Gastric Cancer Model. Tumor Biol. 36 (7), 5215-5223. doi:10.1007/s13277-015-3178-8

Daniels, D. L., and Weis, W. I. (2005). $\beta$-Catenin Directly Displaces Groucho/TLE Repressors from Tcf/Lef in Wnt-Mediated Transcription Activation. Nat. Struct. Mol. Biol. 12 (4), 364-371. doi:10.1038/nsmb912

Das, S. K., Maji, S., Wechman, S. L., Bhoopathi, P., Pradhan, A. K., Talukdar, S., et al. (2020). MDA-9/Syntenin (SDCBP): Novel Gene and Therapeutic Target for Cancer Metastasis. Pharmacol. Res. 155, 104695. doi:10.1016/ j.phrs.2020.104695

de Campos, P. S., Matte, B. F., Diel, L. F., Jesus, L. H., Bernardi, L., Alves, A. M., et al. (2017). Low Doses ofCurcuma longaModulates Cell Migration and CellCell Adhesion. Phytother. Res. 31 (9), 1433-1440. doi:10.1002/ptr.5872

Deepak, K. G. K., Vempati, R., Nagaraju, G. P., Dasari, V. R., S., N., Rao, D. N., et al. (2020). Tumor Microenvironment: Challenges and Opportunities in Targeting Metastasis of Triple Negative Breast Cancer. Pharmacol. Res. 153, 104683. doi:10.1016/j.phrs.2020.104683

Doumiati, S., Haupt, K., and Rossi, C. (2012). Autophosphorylation Activation and Inhibition by Curcumin of the Epidermal Growth Factor Receptor Reconstituted in Liposomes. J. Mol. Recognit. 25 (11), 623-629. doi:10.1002/ jmr.2194

Du, Y., Long, Q., Zhang, L., Shi, Y., Liu, X., Li, X., et al. (2015). Curcumin Inhibits Cancer-Associated Fibroblast-Driven Prostate Cancer Invasion through MAOA/mTOR/HIF-1a Signaling. Int. J. Oncol. 47 (6), 2064-2072. doi:10.3892/ijo.2015.3202

Egeblad, M., and Werb, Z. (2002). New Functions for the Matrix Metalloproteinases in Cancer Progression. Nat. Rev. Cancer 2 (3), 161-174. doi: $10.1038 / \mathrm{nrc} 745$

Esmatabadi, M. J. D., Farhangi, B., Safari, Z., Kazerooni, H., Shirzad, H., Zolghadr, F., et al. (2015). Dendrosomal Curcumin Inhibits Metastatic Potential of Human SW480 colon Cancer Cells through Down-Regulation of Claudin1, Zeb1 and Hef1-1 Gene Expression. Asian Pac. J. Cancer Prev. 16 (6), 2473-2481. doi:10.7314/apjcp.2015.16.6.2473

Faleiro-Rodrigues, C., Macedo-Pinto, I., Pereira, D., and Lopes, C. S. (2004). Prognostic Value of E-Cadherin Immunoexpression in Patients with Primary Ovarian Carcinomas. Ann. Oncol. 15 (10), 1535-1542. doi:10.1093/annonc/mdh387

Fan, C.-C., Wang, T.-Y., Cheng, Y.-A., Jiang, S. S., Cheng, C.-W., Lee, A. Y.-L., et al. (2013). Expression of E-Cadherin, Twist, and P53 and Their Prognostic Value in Patients with Oral Squamous Cell Carcinoma. J. Cancer Res. Clin. Oncol. 139 (10), 1735-1744. doi:10.1007/s00432-013-1499-9

Fan, L., Li, A., Li, W., Cai, P., Yang, B., Zhang, M., et al. (2014). Novel Role of Sarco/ endoplasmic Reticulum Calcium ATPase 2 in Development of Colorectal Cancer and its Regulation by F36, a Curcumin Analog. Biomed. Pharmacother. 68 (8), 1141-1148. doi:10.1016/j.biopha.2014.10.014

Fan, R., Li, X., Deng, J., Gao, X., Zhou, L., Zheng, Y., et al. (2016). Dual Drug Loaded Biodegradable Nanofibrous Microsphere for Improving Anti-Colon Cancer Activity. Sci. Rep. 6, 28373. doi:10.1038/srep28373

Fischer-Fodor, E., Miklas, R., Risianova, L., Cenariu, M., Grosu, I. G., Virag, P., et al. (2017). Novel Palladium(II) Complexes that Influence Prominin-1/CD133 Expression and Stem Cell Factor Release in Tumor Cells. Molecules 22 (4). doi:10.3390/molecules22040561

Fodde, R., and Brabletz, T. (2007). Wnt/ $/$-catenin Signaling in Cancer Stemness and Malignant Behavior. Curr. Opin. Cel Biol. 19 (2), 150-158. doi:10.1016/ j.ceb.2007.02.007

Fouad, Y. A., and Aanei, C. (2017). Revisiting the Hallmarks of Cancer. Am. J. Cancer Res. 7 (5), 1016-1036.

Fouani, L., Menezes, S. V., Paulson, M., Richardson, D. R., and Kovacevic, Z. (2017). Metals and Metastasis: Exploiting the Role of Metals in Cancer Metastasis to Develop Novel Anti-metastatic Agents. Pharmacol. Res. 115, 275-287. doi:10.1016/j.phrs.2016.12.001

Francí, C., Takkunen, M., Dave, N., Alameda, F., Gómez, S., Rodríguez, R., et al. (2006). Expression of Snail Protein in Tumor-Stroma Interface. Oncogene 25 (37), 5134-5144. doi:10.1038/si.onc.1209519 
Franco, R., Pirozzi, G., Scala, S., Cantile, M., Scognamiglio, G., Camerlingo, R., et al. (2012). CXCL12-binding Receptors Expression in Non-small Cell Lung Cancer Relates to Tumoral Microvascular Density and CXCR4 Positive Circulating Tumoral Cells in Lung Draining Venous Blood. Eur. J. Cardio-Thoracic Surg. 41 (2), 368-375. doi:10.1016/j.ejcts.2011.05.009

Friedl, P. (2004). Prespecification and Plasticity: Shifting Mechanisms of Cell Migration. Curr. Opin. Cel Biol. 16 (1), 14-23. doi:10.1016/j.ceb.2003.11.001

Greil, R., Greil-Ressler, S., Weiss, L., Schönlieb, C., Magnes, T., Radl, B., et al. (2018). A Phase 1 Dose-Escalation Study on the Safety, Tolerability and Activity of Liposomal Curcumin (Lipocurc) in Patients with Locally Advanced or Metastatic Cancer. Cancer Chemother. Pharmacol. 82 (4), 695-706. doi:10.1007/s00280-018-3654-0

Gu, X., Zhang, Q., Zhang, W., and Zhu, L. (2019). Curcumin Inhibits Liver Metastasis of Gastric Cancer through Reducing Circulating Tumor Cells. Aging 11 (5), 1501-1509. doi:10.18632/aging.101848

Guerrero, S., Inostroza-Riquelme, M., Contreras-Orellana, P., Diaz-Garcia, V., Lara, P., Vivanco-Palma, A., et al. (2018). Curcumin-loaded Nanoemulsion: a New Safe and Effective Formulation to Prevent Tumor Reincidence and Metastasis. Nanoscale 10 (47), 22612-22622. doi:10.1039/c8nr06173d

Gundem, G., au, fnm., Van Loo, P., Kremeyer, B., Alexandrov, L. B., Tubio, J. M. C., et al. (2015). The Evolutionary History of Lethal Metastatic Prostate Cancer. Nature 520 (7547), 353-357. doi:10.1038/nature14347

Han, H., Wei, W., Chu, W., Liu, K., Tian, Y., Jiang, Z., et al. (2017). Muscle Conditional Medium Reduces Intramuscular Adipocyte Differentiation and Lipid Accumulation through Regulating Insulin Signaling. Int. J. Mol. Sci. 18 (8). doi:10.3390/ijms18081799

Han, Y. P., Tuan, T. L., Wu, H., Hughes, M., and Garner, W. L., (2001). TNF-alpha Stimulates Activation of Pro-MMP2 in Human Skin through NF-(kappa)B Mediated Induction of MT1-MMP. J. Cel Sci 114 (Pt 1), 131-139. doi:10.1242/ jcs.114.1.131

Hanahan, D., and Weinberg, R. A. (2011). Hallmarks of Cancer: the Next Generation. Cell 144 (5), 646-674. doi:10.1016/j.cell.2011.02.013

Hatakeyama, K., Yamakawa, Y., Fukuda, Y., Ohshima, K., Wakabayashi-Nakao, K., Sakura, N., et al. (2015). A Novel Splice Variant of XIAP-Associated Factor 1 (XAF1) Is Expressed in Peripheral Blood Containing Gastric Cancer-Derived Circulating Tumor Cells. Gastric Cancer 18 (4), 751-761. doi:10.1007/s10120014-0426-3

Helson, L., Bolger, G., Majeed, M., Vcelar, B., Pucaj, K., and Matabudul, D. (2012). Infusion Pharmacokinetics of Lipocurc ${ }^{\mathrm{TM}}$ (Liposomal Curcumin) and its Metabolite Tetrahydrocurcumin in Beagle Dogs. Anticancer Res. 32 (10), 4365-4370.

Hong, J. H., Ahn, K. S., Bae, E., Jeon, S. S., and Choi, H. Y. (2006). The Effects of Curcumin on the Invasiveness of Prostate Cancer In Vitro and In Vivo. Prostate Cancer Prostatic Dis. 9 (2), 147-152. doi:10.1038/sj.pcan.4500856

Hosseini, S. A., Zand, H., and Cheraghpour, M. (2019). The Influence of Curcumin on the Downregulation of MYC, Insulin and IGF-1 Receptors: A Possible Mechanism Underlying the Anti-growth and Anti-migration in Chemoresistant Colorectal Cancer Cells. Medicina (Kaunas) 55 (4). doi:10.3390/medicina55040090

Huang, M. T., Lou, Y. R., Ma, W., Newmark, H. L., Reuhl, K. R., and Conney, A. H. (1994). Inhibitory Effects of Dietary Curcumin on Forestomach, Duodenal, and colon Carcinogenesis in Mice. Cancer Res. 54 (22), 5841-5847.

Huang, X., Gan, G., Wang, X., Xu, T., and Xie, W. (2019). The HGF-MET axis Coordinates Liver Cancer Metabolism and Autophagy for Chemotherapeutic Resistance. Autophagy 15 (7), 1258-1279. doi:10.1080/15548627.2019.1580105

Huber, G. F., Züllig, L., Soltermann, A., Roessle, M., Graf, N., Haerle, S. K., et al. (2011). Down Regulation of E-Cadherin (ECAD) - a Predictor for Occult Metastatic Disease in sentinel Node Biopsy of Early Squamous Cell Carcinomas of the Oral Cavity and Oropharynx. BMC Cancer 11 (217), 1-8. doi:10.1186/ 1471-2407-11-217

Inano, H., Onoda, M., Inafuku, N., Kubota, M., Kamada, Y., Osawa, T., et al. (1999). Chemoprevention by Curcumin during the Promotion Stage of Tumorigenesis of Mammary Gland in Rats Irradiated with Gamma-Rays. Carcinogenesis 20 (6), 1011-1018. doi:10.1093/carcin/20.6.1011

Ismail, N. I., and Othman, I. (2019). Mechanism of Apoptosis Induced by Curcumin in Colorectal Cancer. Int. J. Mol. Sci. 20(10).doi:10.3390/ ijms20102454
Izzo, J. G., Correa, A. M., Wu, T.-T., Malhotra, U., Chao, C. K. S., Luthra, R., et al. (2006). Pretherapy Nuclear Factor-Kb Status, Chemoradiation Resistance, and Metastatic Progression in Esophageal Carcinoma. Mol. Cancer Ther. 5 (11), 2844-2850. doi:10.1158/1535-7163.mct-06-0351

Jiao, D., Jian, W., Lu, W., TangChen, X. J., Mou, H., et al. (2016). Curcumin Inhibited HGF-Induced EMT and Angiogenesis through Regulating C-Met Dependent PI3K/Akt/mTOR Signaling Pathways in Lung Cancer. Mol. Ther. Oncolytics 3, 16018. doi:10.1038/mto.2016.18

Kaifi, J. T., Yekebas, E. F., Schurr, P., Obonyo, D., Wachowiak, R., Busch, P., et al. (2005). Tumor-cell Homing to Lymph Nodes and Bone Marrow and CXCR4 Expression in Esophageal Cancer. J. Natl. Cancer Inst. 97 (24), 1840-1847. doi:10.1093/jnci/dji431

Kalluri, R., and Zeisberg, M. (2006). Fibroblasts in Cancer. Nat. Rev. Cancer 6 (5), 392-401. doi:10.1038/nrc1877

Kasashima, H., Yashiro, M., Kinoshita, H., Fukuoka, T., Morisaki, T., Masuda, G. et al. (2014). Lysyl Oxidase-like 2 (LOXL2) from Stromal Fibroblasts Stimulates the Progression of Gastric Cancer. Cancer Lett. 354 (2), 438-446. doi:10.1016/ j.canlet.2014.08.014

Katsuno, Y., Lamouille, S., and Derynck, R. (2013). TGF- $\beta$ Signaling and EpithelialMesenchymal Transition in Cancer Progression. Curr. Opin. Oncol. 25 (1), 76-84. doi:10.1097/cco.0b013e32835b6371

Kim, D.-C., Lee, W., and Bae, J.-S. (2011). Vascular Anti-inflammatory Effects of Curcumin on HMGB1-Mediated Responses In Vitro. Inflamm. Res. 60 (12), 1161-1168. doi:10.1007/s00011-011-0381-y

Kim, H. J., Park, S. Y., Park, O. J., and Kim, Y.-M. (2013). Curcumin Suppresses Migration and Proliferation of Hep3B Hepatocarcinoma Cells through Inhibition of the Wnt Signaling Pathway. Mol. Med. Rep. 8 (1), 282-286. doi:10.3892/mmr.2013.1497

Kim, J.-M., Noh, E.-M., Kwon, K.-B., Kim, J.-S., You, Y.-O., Hwang, J.-K., et al. (2012). Curcumin Suppresses the TPA-Induced Invasion through Inhibition of PKCa-dependent MMP-Expression in MCF-7 Human Breast Cancer Cells. Phytomedicine 19 (12), 1085-1092. doi:10.1016/j.phymed.2012.07.002

Kim, J. H., Gupta, S. C., Park, B., Yadav, V. R., and Aggarwal, B. B. (2012). Turmeric (Curcuma Longa ) Inhibits Inflammatory Nuclear Factor (NF)- $\mathrm{BB}$ and NF-KbRegulated Gene Products and Induces Death Receptors Leading to Suppressed Proliferation, Induced Chemosensitization, and Suppressed Osteoclastogenesis. Mol. Nutr. Food Res. 56 (3), 454-465. doi:10.1002/mnfr.201100270

Knott, S. R. V., Wagenblast, E., Khan, S., Kim, S. Y., Soto, M., Wagner, M., et al. (2018). Asparagine Bioavailability Governs Metastasis in a Model of Breast Cancer. Nature 554 (7692), 378-381. doi:10.1038/nature25465

Kunnumakkara, A. B., Diagaradjane, P., Anand, P., Kuzhuvelil, H. B., Deorukhkar, A., Gelovani, J., et al. (2009). Curcumin Sensitizes Human Colorectal Cancer to Capecitabine by Modulation of Cyclin D1, COX-2, MMP-9, VEGF and CXCR4 Expression in an Orthotopic Mouse Model. Int. J. Cancer 125 (9), 2187-2197. doi: $10.1002 /$ ijc. 24593

Lambert, A. W., Pattabiraman, D. R., and Weinberg, R. A. (2017). Emerging Biological Principles of Metastasis. Cell 168 (4), 670-691. doi:10.1016/ j.cell.2016.11.037

Larsson, S. C., Orsini, N., and Wolk, A. (2005). Diabetes Mellitus and Risk of Colorectal Cancer: a Meta-Analysis. J. Natl. Cancer Inst. 97 (22), 1679-1687. doi:10.1093/jnci/dji375

Lee, A. Y.-L., Fan, C.-C., Chen, Y.-A., Cheng, C.-W., Sung, Y.-J., Hsu, C.-P., et al. (2015). Curcumin Inhibits Invasiveness and Epithelial-Mesenchymal Transition in Oral Squamous Cell Carcinoma through Reducing Matrix Metalloproteinase 2, 9 and Modulating P53-E-Cadherin Pathway. Integr. Cancer Ther. 14 (5), 484-490. doi:10.1177/1534735415588930

Lee, B. C., Lee, T. H., Avraham, S., and Avraham, H. K. (2004). Involvement of the Chemokine Receptor CXCR4 and its Ligand Stromal Cell-Derived Factor 1alpha in Breast Cancer Cell Migration through Human Brain Microvascular Endothelial Cells. Mol. Cancer Res. 2 (6), 327-338.

Lee, D. J., and Kang, S. W. (2013). RETRACTED ARTICLE: Reactive Oxygen Species and Tumor Metastasis. Mol. Cell 35 (2), 93-98. doi:10.1007/s10059013-0034-9

Lee, J.-G., McKinney, K. Q., Pavlopoulos, A. J., Park, J.-H., and Hwang, S. (2014). Data Supporting the Identification of Anti-metastatic Drug and Natural Compound Targets in Isogenic Colorectal Cancer Cells. Data in Brief 1, 73-75. doi:10.1016/j.dib.2014.10.005 
Lee, J.-G., McKinney, K. Q., Pavlopoulos, A. J., Park, J.-H., and Hwang, S. (2015). Identification of Anti-metastatic Drug and Natural Compound Targets in Isogenic Colorectal Cancer Cells. J. Proteomics 113, 326-336. doi:10.1016/ j.jprot.2014.10.009

Lee, S. S., et al. (2013). Elevated Snail Expression Mediates Tumor Progression in Areca Quid Chewing-Associated Oral Squamous Cell Carcinoma via Reactive Oxygen Species. PLoS One 8 (7), e67985. doi:10.1371/journal.pone.0067985

Lei, J., Ma, J., Ma, Q., Li, X., Liu, H., Xu, Q., et al. (2013). Hedgehog Signaling Regulates Hypoxia Induced Epithelial to Mesenchymal Transition and Invasion in Pancreatic Cancer Cells via a Ligand-independent Manner. Mol. Cancer 12, 66. doi:10.1186/1476-4598-12-66

Li, L., Ahmed, B., Mehta, K., and Kurzrock, R. (2007). Liposomal Curcumin with and without Oxaliplatin: Effects on Cell Growth, Apoptosis, and Angiogenesis in Colorectal Cancer. Mol. Cancer Ther. 6 (4), 1276-1282. doi:10.1158/15357163.mct-06-0556

Li, L., Braiteh, F. S., and Kurzrock, R. (2005). Liposome-encapsulated Curcumin. Cancer 104 (6), 1322-1331. doi:10.1002/cncr.21300

Li, M., Yue, G. G.-L., Tsui, S. K.-W., Fung, K.-P., and Lau, C. B.-S. (2018). Turmeric Extract, with Absorbable Curcumin, Has Potent Anti-metastatic Effect In Vitro and In Vivo. Phytomedicine 46, 131-141. doi:10.1016/j.phymed.2018.03.065

Li, W., Jiang, Z., Xiao, X., Wang, Z., Wu, Z., Ma, Q., et al. (2018). Curcumin Inhibits Superoxide Dismutase-Induced Epithelial-To-Mesenchymal Transition via the PI3K/Akt/NF-Kb Pathway in Pancreatic Cancer Cells. Int. J. Oncol. 52 (5), 1593-1602. doi:10.3892/ijo.2018.4295

Li, W., Ma, Z., Ma, J., Li, X., Xu, Q., Duan, W., et al. (2015). Hydrogen Peroxide Mediates Hyperglycemia-Induced Invasive Activity via ERK and P38 MAPK in Human Pancreatic Cancer. Oncotarget 6 (31), 31119-31133. doi:10.18632/ oncotarget.5045

Liang, Z., Lu, L., Mao, J., Li, X., Qian, H., Xu, W., et al. (2017). Curcumin Reversed Chronic Tobacco Smoke Exposure Induced Urocystic EMT and Acquisition of Cancer Stem Cells Properties via Wnt/ $\beta$-Catenin. Cell Death Dis 8 (10), e3066. doi:10.1038/cddis.2017.452

Lima, F. T., Eloy, J. O., Ruiz, A., Petrilli, R., Raspantini, G., Nogueira, K. A. B., et al. (2018). The Curcumin Analog CH-5 Exerts Anticancer Effects in Human Osteosarcoma Cells via Modulation of Transcription Factors p53/Sp1. Int. J. Mol. Sci. 19 (7). doi:10.3390/ijms19071909

Lin, L.-I., Ke, Y.-F., Ko, Y.-C., and Lin, J.-K. (1998). Curcumin Inhibits SK-Hep-1 Hepatocellular Carcinoma Cell Invasion In Vitro and Suppresses Matrix Metalloproteinase-9 Secretion. Oncology 55 (4), 349-353. doi:10.1159/ 000011876

Lin, L., Fuchs, J., Li, C., Olson, V., Bekaii-Saab, T., Lin, J., et al. (2011). STAT3 Signaling Pathway Is Necessary for Cell Survival and Tumorsphere Forming Capacity in $\mathrm{ALDH}^{+} / \mathrm{CD} 133^{+}$Stem Cell-like Human colon Cancer Cells. Biochem. Biophys. Res. Commun. 416 (3-4), 246-251. doi:10.1016/ j.bbrc.2011.10.112

Lin, M.-C., Huang, M.-J., Liu, C.-H., Yang, T.-L., and Huang, M.-C. (2014). GALNT2 Enhances Migration and Invasion of Oral Squamous Cell Carcinoma by Regulating EGFR Glycosylation and Activity. Oral Oncol. 50 (5), 478-484. doi:10.1016/j.oraloncology.2014.02.003

Lin, M.-L., Lu, Y.-C., Chen, H.-Y., Lee, C.-C., Chung, J.-G., and Chen, S.-S. (2014). Suppressing the Formation of Lipid Raft-Associated Rac1/PI3K/Akt Signaling Complexes by Curcumin Inhibits SDF-1a-Induced Invasion of Human Esophageal Carcinoma Cells. Mol. Carcinog. 53 (5), 360-379. doi:10.1002/ mc. 21984

Lin, S.-S., Lai, K.-C., Hsu, S.-C., Yang, J.-S., Kuo, C.-L., Lin, J.-P., et al. (2009). Curcumin Inhibits the Migration and Invasion of Human A549 Lung Cancer Cells through the Inhibition of Matrix Metalloproteinase-2 and - 9 and Vascular Endothelial Growth Factor (VEGF). Cancer Lett. 285 (2), 127-133. doi:10.1016/ j.canlet.2009.04.037

Lintz, M., Muñoz, A., and Reinhart-King, C. A. (2017). The Mechanics of Single Cell and Collective Migration of Tumor Cells. J. biomechanical Eng. 139 (2), 0210051-0210059. doi:10.1115/1.4035121

Liu, D., Liu, J., Wang, C., Lin, B., Liu, Q., Hao, Y., et al. (2011). The Stimulation of IGF-1R Expression by Lewis(y) Antigen Provides a Powerful Development Mechanism of Epithelial Ovarian Carcinoma. Ijms 12 (10), 6781-6795. doi:10.3390/ijms12106781

Liu, W. L., Chang, J. M., Chong, I. W., Hung, Y. L., Chen, Y. H., Huang, W. T., et al. (2017). Curcumin Inhibits LIN-28A through the Activation of miRNA-98 in the Lung Cancer Cell Line A549. Molecules 22 (6). doi:10.3390/ molecules22060929

Lunardi, S., Muschel, R. J., and Brunner, T. B. (2014). The Stromal Compartments in Pancreatic Cancer: Are There Any Therapeutic Targets? Cancer Lett. 343 (2), 147-155. doi:10.1016/j.canlet.2013.09.039

Luo, X., Liu, J., Wang, H., and Lu, H. (2020). Metabolomics Identified New Biomarkers for the Precise Diagnosis of Pancreatic Cancer and Associated Tissue Metastasis. Pharmacol. Res. 156, 104805. doi:10.1016/j.phrs.2020.104805

Luzzi, K. J., MacDonald, I. C., Schmidt, E. E., Kerkvliet, N., Morris, V. L., Chambers, A. F., et al. (1998). Multistep Nature of Metastatic Inefficiency. Am. J. Pathol. 153 (3), 865-873. doi:10.1016/s0002-9440(10)65628-3

Lv, X.-P. (2017). Gastrointestinal Tract Cancers: Genetics, Heritability and Germ Line Mutations. Oncol. Lett. 13 (3), 1499-1508. doi:10.3892/ol.2017.5629

Mach, C. M., Mathew, L., Mosley, S. A., Kurzrock, R., and Smith, J. A. (2009). Determination of Minimum Effective Dose and Optimal Dosing Schedule for Liposomal Curcumin in a Xenograft Human Pancreatic Cancer Model. Anticancer Res. 29 (6), 1895-1899.

Madamsetty, V. S., Pal, K., Keshavan, S., Caulfield, T. R., Dutta, S. K., Wang, E., et al. (2019). Development of Multi-Drug Loaded PEGylated Nanodiamonds to Inhibit Tumor Growth and Metastasis in Genetically Engineered Mouse Models of Pancreatic Cancer. Nanoscale 11 (45), 22006-22018. doi:10.1039/ c9nr05478b

Maitra, A. (2019). Molecular Envoys Pave the Way for Pancreatic Cancer to Invade the Liver. Nature 567 (7747), 181-182. doi:10.1038/d41586-019-00710-z

Mardani, R., Hamblin, M. R., Taghizadeh, M., Banafshe, H. R., Nejati, M., Mokhtari, M., et al. (2020). Nanomicellar-curcumin Exerts its Therapeutic Effects via Affecting Angiogenesis, Apoptosis, and T Cells in a Mouse Model of Melanoma Lung Metastasis. Pathol. - Res. Pract. 216 (9), 153082. doi:10.1016/ j.prp.2020.153082

Martin, T. A., Goyal, A., Watkins, G., and Jiang, W. G. (2005). Expression of the Transcription Factors Snail, Slug, and Twist and Their Clinical Significance in Human Breast Cancer. Ann. Surg. Oncol. 12 (6), 488-496. doi:10.1245/ aso.2005.04.010

Maseki, S., Ijichi, K., Nakanishi, H., Hasegawa, Y., Ogawa, T., and Murakami, S. (2013). Efficacy of Gemcitabine and Cetuximab Combination Treatment in Head and Neck Squamous Cell Carcinoma. Mol. Clin. Oncol. 1 (5), 918-924. doi:10.3892/mco.2013.159

Massagué, J., and Obenauf, A. C. (2016). Metastatic Colonization by Circulating Tumour Cells. Nature 529 (7586), 298-306. doi:10.1038/nature17038

Masuda, T., Maekawa, T., Hidaka, K., Bando, H., Takeda, Y., and Yamaguchi, H. (2001). Chemical Studies on Antioxidant Mechanism of Curcumin: Analysis of Oxidative Coupling Products from Curcumin and Linoleate. J. Agric. Food Chem. 49 (5), 2539-2547. doi:10.1021/jf001442x

Matabudul, D., Pucaj, K., Bolger, G., Vcelar, B., Majeed, M., and Helson, L. (2012). Tissue Distribution of (Lipocurc ${ }^{\mathrm{TM}}$ ) Liposomal Curcumin and Tetrahydrocurcumin Following Two- and Eight-Hour Infusions in Beagle Dogs. Anticancer Res. 32 (10), 4359-4364.

Mego, M., Rejlekova, K., Reckova, M., Sycova-Mila, Z., Obertova, J., Rajec, J., et al. (2016). CXCR4-SDF-1 Interaction Potentially Mediates Trafficking of Circulating Tumor Cells in Primary Breast Cancer. BMC Cancer 16, 127. doi:10.1186/s12885-016-2143-2

Mitra, A., Chakrabarti, J., Banerji, A., Chatterjee, A., and Das, B. R. (2006). Curcumin, a Potential Inhibitor of MMP-2 in Human Laryngeal Squamous Carcinoma Cells HEp2. J. Environ. Pathol. Toxicol. Oncol. 25 (4), 679-690. doi:10.1615/jenvironpatholtoxicoloncol.v25.i4.70

Mohan, R., Sivak, J., Ashton, P., Russo, L. A., Pham, B. Q., Kasahara, N., et al. (2000). Curcuminoids Inhibit the Angiogenic Response Stimulated by Fibroblast Growth Factor-2, Including Expression of Matrix Metalloproteinase Gelatinase B. J. Biol. Chem. 275 (14), 10405-10412. doi:10.1074/jbc.275.14.10405

Mudduluru, G., George-William, J. N., Muppala, S., Asangani, I. A., Kumarswamy, R., Nelson, L. D., et al. (2011). Curcumin Regulates miR-21 Expression and Inhibits Invasion and Metastasis in Colorectal Cancer. Biosci. Rep. 31 (3), 185-197. doi:10.1042/bsr20100065

Mukherjee, S., Hussaini, R., White, R., Atwi, D., Fried, A., Sampat, S., et al. (2018). TriCurin, a Synergistic Formulation of Curcumin, Resveratrol, and Epicatechin Gallate, Repolarizes Tumor-Associated Macrophages and Triggers an Immune Response to Cause Suppression of HPV+ Tumors. 
Cancer Immunol. Immunotherimmunotherapy 67 (5), 761-774. doi:10.1007/s00262-018-2130-3

Müller, A., Homey, B., Soto, H., Ge, N., Catron, D., Buchanan, M. E., et al. (2001). Involvement of Chemokine Receptors in Breast Cancer Metastasis. Nature 410 (6824), 50-56. doi:10.1038/35065016

Muñoz, P., Iliou, M. S., and Esteller, M. (2012). Epigenetic Alterations Involved in Cancer Stem Cell Reprogramming. Mol. Oncol. 6 (6), 620-636. doi:10.1016/ j.molonc.2012.10.006

Murphy, G., and Nagase, H. (2008). Progress in Matrix Metalloproteinase Research. Mol. Aspects Med. 29 (5), 290-308. doi:10.1016/j.mam.2008.05.002

Nagaraju, G. P., Zhu, S., Ko, J. E., Ashritha, N., Kandimalla, R., Snyder, J. P., et al. (2015). Antiangiogenic Effects of a Novel Synthetic Curcumin Analogue in Pancreatic Cancer. Cancer Lett. 357 (2), 557-565. doi:10.1016/ j.canlet.2014.12.007

Nechushtan, H., Vainer, G., Stainberg, H., Salmon, A. Y., Hamburger, T., and Peretz, T. (2014). A Phase $1 / 2$ of a Combination of Cetuximab and Taxane for "triple Negative" Breast Cancer Patients. The Breast 23 (4), 435-438. doi:10.1016/j.breast.2014.03.003

Negi, P. S., Jayaprakasha, G. K., Jagan Mohan Rao, L., and Sakariah, K. K. (1999). Antibacterial Activity of Turmeric Oil: a Byproduct from Curcumin Manufacture. J. Agric. Food Chem. 47 (10), 4297-4300. doi:10.1021/jf990308d

Nieto, M. A., Huang, R. Y.-J., Jackson, R. A., and Thiery, J. P. (2016). EMT: 2016. Cell 166 (1), 21-45. doi:10.1016/j.cell.2016.06.028

Nishikawa, M., Hashida, M., and Takakura, Y. (2009). Catalase Delivery for Inhibiting ROS-Mediated Tissue Injury and Tumor Metastasis. Adv. Drug Deliv. Rev. 61 (4), 319-326. doi:10.1016/j.addr.2009.01.001

Ohnishi, Y., Sakamoto, T., Zhengguang, L., Yasui, H., Hamada, H., Kubo, H., et al. (2020). Curcumin Inhibits Epithelial-Mesenchymal Transition in Oral Cancer Cells via C-Met Blockade. Oncol. Lett. 19 (6), 4177-4182. doi:10.3892/ ol.2020.11523

Orrù, S., and Nigro, E. (2017). A Functional Interplay between IGF-1 and Adiponectin. Int. J. Mol. Sci. 18 (10), 2145. doi:10.3390/ijms18102145

Pan, P., Huang, Y.-W., Oshima, K., Yearsley, M., Zhang, J., Arnold, M., et al. (2019). The Immunomodulatory Potential of Natural Compounds in TumorBearing Mice and Humans. Crit. Rev. Food Sci. Nutr. 59 (6), 992-1007. doi:10.1080/10408398.2018.1537237

Panda, A., Grammatikakis, I., Yoon, J.-H., and Abdelmohsen, K. (2013). Posttranscriptional Regulation of Insulin Family Ligands and Receptors. Ijms 14 (9), 19202-19229. doi:10.3390/ijms140919202

Parasramka, M. A., and Gupta, S. V. (2012). Synergistic Effect of Garcinol and Curcumin on Antiproliferative and Apoptotic Activity in Pancreatic Cancer Cells. J. Oncol. 2012, 709739. doi:10.1155/2012/709739

Pastushenko, I., Brisebarre, A., Sifrim, A., Fioramonti, M., Revenco, T., Boumahdi, S., et al. (2018). Identification of the Tumour Transition States Occurring during EMT. Nature 556 (7702), 463-468. doi:10.1038/s41586-018-0040-3

Philip, S., Bulbule, A., and Kundu, G. C. (2004). Matrix Metalloproteinase-2: Mechanism and Regulation of NF-kappaB-Mediated Activation and its Role in Cell Motility and ECM-Invasion. Glycoconj J. 21 (8-9), 429-441. doi:10.1007/ s10719-004-5533-7

Philip, S., Bulbule, A., and Kundu, G. C. (2001). Osteopontin Stimulates Tumor Growth and Activation of Promatrix Metalloproteinase-2 through Nuclear Factor-Kb-Mediated Induction of Membrane Type 1 Matrix Metalloproteinase in Murine Melanoma Cells. J. Biol. Chem. 276 (48), 44926-44935. doi:10.1074/ jbc.m103334200

Philip, S., and Kundu, G. C. (2003). Osteopontin Induces Nuclear Factor кBmediated Promatrix Metalloproteinase-2 Activation through IKBa/IKK Signaling Pathways, and Curcumin (Diferulolylmethane) Down-Regulates These Pathways. J. Biol. Chem. 278 (16), 14487-14497. doi:10.1074/ jbc.m207309200

Pike, L. J. (2005). Growth Factor Receptors, Lipid Rafts and Caveolae: an Evolving story. Biochim. Biophys. Acta (Bba) - Mol. Cel Res. 1746 (3), 260-273. doi:10.1016/j.bbamcr.2005.05.005

Rabinowits, G., and Haddad, R. I. (2012). Overcoming Resistance to EGFR Inhibitor in Head and Neck Cancer: a Review of the Literature. Oral Oncol. 48 (11), 1085-1089. doi:10.1016/j.oraloncology.2012.06.016

Ranjan, A. P., Mukerjee, A., Helson, L., Gupta, R., and Vishwanatha, J. K. (2013). Efficacy of Liposomal Curcumin in a Human Pancreatic Tumor Xenograft
Model: Inhibition of Tumor Growth and Angiogenesis. Anticancer Res. 33 (9), 3603-3609.

Rashmi, R., Kumar, S., and Karunagaran, D. (2004). Ectopic Expression of Hsp70 Confers Resistance and Silencing its Expression Sensitizes Human colon Cancer Cells to Curcumin-Induced Apoptosis. Carcinogenesis 25 (2), 179-187. doi:10.1093/carcin/bgh213

Rath, S., Das, L., Kokate, S. B., Ghosh, N., Dixit, P., Rout, N., et al. (2017). Inhibition of Histone/lysine Acetyltransferase Activity Kills CoCl2-Treated and HypoxiaExposed Gastric Cancer Cells and Reduces Their Invasiveness. Int. J. Biochem. Cel Biol. 82, 28-40. doi:10.1016/j.biocel.2016.11.014

Reckamp, K. L., Figlin, R. A., Burdick, M. D., Dubinett, S. M., Elashoff, R. M., Strieter, R. M., et al. (2009). CXCR4 Expression on Circulating Pan-Cytokeratin Positive Cells Is Associated with Survival in Patients with Advanced Non-small Cell Lung Cancer. BMC Cancer 9, 213. doi:10.1186/1471-2407-9-213

Richmond, P. J., Karayiannakis, A. J., Nagafuchi, A., Kaisary, A. V., and Pignatelli, M. (1997). Aberrant E-Cadherin and Alpha-Catenin Expression in Prostate Cancer: Correlation with Patient Survival. Cancer Res. 57 (15), 3189-3193.

Roberts, P. J., and Der, C. J. (2007). Targeting the Raf-MEK-ERK MitogenActivated Protein Kinase cascade for the Treatment of Cancer. Oncogene 26 (22), 3291-3310. doi:10.1038/sj.onc.1210422

Rosivatz, E., Becker, I., Specht, K., Fricke, E., Luber, B., Busch, R., et al. (2002). Differential Expression of the Epithelial-Mesenchymal Transition Regulators Snail, SIP1, and Twist in Gastric Cancer. Am. J. Pathol. 161 (5), 1881-1891. doi:10.1016/s0002-9440(10)64464-1

Roy, S. (2013). Difluorinated-curcumin (CDF) Restores PTEN Expression in colon Cancer Cells by Down-Regulating miR-21. PLoS One 8 (7), e68543. doi:10.1371/journal.pone.0068543

Roy, S., Levi, E., Majumdar, A. P., and Sarkar, F. H. (2012). Expression of miR-34 Is Lost in colon Cancer Which Can Be Re-expressed by a Novel Agent CDF. J. Hematol. Oncol. 5, 58. doi:10.1186/1756-8722-5-58

Saito, H., Takaya, S., Osaki, T., and Ikeguchi, M. (2013). Increased Apoptosis and Elevated Fas Expression in Circulating Natural Killer Cells in Gastric Cancer Patients. Gastric Cancer 16 (4), 473-479. doi:10.1007/s10120-012-0210-1

Sankpal, U. T., Nagaraju, G. P., Gottipolu, S. R., Hurtado, M., Jordan, C. G., Simecka, J. W., et al. (2016). Combination of Tolfenamic Acid and Curcumin Induces colon Cancer Cell Growth Inhibition through Modulating Specific Transcription Factors and Reactive Oxygen Species. Oncotarget 7 (3), 3186-3200. doi:10.18632/oncotarget.6553

Sarfstein, R., Belfiore, A., and Werner, H. (2010). Identification of Insulin-like Growth Factor-I Receptor (IGF-IR) Gene Promoter-Binding Proteins in Estrogen Receptor (ER)-Positive and ER-Depleted Breast Cancer Cells. Cancers 2 (2), 233-261. doi:10.3390/cancers2020233

Satoskar, R. R., Shah, S. J., and Shenoy, S. G. (1986). Evaluation of Antiinflammatory Property of Curcumin (Diferuloyl Methane) in Patients with Postoperative Inflammation. Int. J. Clin. Pharmacol. Ther. Toxicol. 24 (12), 651-654.

Sgambato, A., Casaluce, F., Maione, P., Rossi, A., Ciardiello, F., and Gridelli, C. (2014). Cetuximab in Advanced Non-small Cell Lung Cancer (NSCLC): the Showdown? J. Thorac. Dis. 6 (6), 578-580. doi:10.3978/j.issn.20721439.2014.06.14

Shafabakhsh, R., Pourhanifeh, M. H., Mirzaei, H. R., Sahebkar, A., Asemi, Z., and Mirzaei, H. (2019). Targeting Regulatory T Cells by Curcumin: A Potential for Cancer Immunotherapy. Pharmacol. Res. 147, 104353. doi:10.1016/ j.phrs.2019.104353

Shakibaei, M., John, T., Schulze-Tanzil, G., Lehmann, I., and Mobasheri, A. (2007). Suppression of NF-Kb Activation by Curcumin Leads to Inhibition of Expression of Cyclo-Oxygenase-2 and Matrix Metalloproteinase-9 in Human Articular Chondrocytes: Implications for the Treatment of Osteoarthritis. Biochem. Pharmacol. 73 (9), 1434-1445. doi:10.1016/ j.bcp.2007.01.005

Shakibaei, M., Kraehe, P., Popper, B., Shayan, P., Goel, A., Buhrmann, C., et al. (2015). Curcumin Potentiates Antitumor Activity of 5-fluorouracil in a 3D Alginate Tumor Microenvironment of Colorectal Cancer. BMC Cancer 15, 250. doi:10.1186/s12885-015-1291-0

Shao, Z.-M., Shen, Z.-Z., Liu, C.-H., Sartippour, M. R., Go, V. L., Heber, D., et al. (2002). Curcumin Exerts Multiple Suppressive Effects on Human Breast Carcinoma Cells. Int. J. Cancer 98 (2), 234-240. doi:10.1002/ijc.10183 
Sharma, K. L., and Bhatia, V. (2018). Gastrointestinal Cancers: Molecular Genetics and Biomarkers. Can. J. Gastroenterol. Hepatol. 2018, 4513860. doi:10.1155/ 2018/4513860

Shen, F., Cai, W. S., Li, J. L., Feng, Z., Liu, Q. C., Xiao, H. Q., et al. (2014). Synergism from the Combination of Ulinastatin and Curcumin Offers Greater Inhibition against Colorectal Cancer Liver Metastases via Modulating Matrix Metalloproteinase-9 and E-Cadherin Expression. Onco Targets Ther. 7, 305-314. doi:10.2147/OTT.S57126

Silva, G., Teixeira Lima, F., Seba, V., Mendes Lourenço, A. L., Lucas, T. G., de Andrade, B. V., et al. (2018). Curcumin Analog CH-5 Suppresses the Proliferation, Migration, and Invasion of the Human Gastric Cancer Cell Line HGC-27. Molecules 23 (2). doi:10.3390/molecules23020279

Soeda, H., Shimodaira, H., Gamoh, M., Ando, H., Isobe, H., Suto, T., et al. (2014). Phase II Trial of Cetuximab Plus Irinotecan for Oxaliplatin- and IrinotecanBased Chemotherapy-Refractory Patients with Advanced And/or Metastatic Colorectal Cancer: Evaluation of Efficacy and Safety Based on KRAS Mutation Status (T-Core0801). Oncology 87 (1), 7-20. doi:10.1159/000360989

Soubani, O., Ali, A. S., Logna, F., Ali, S., Philip, P. A., and Sarkar, F. H. (2012). Reexpression of miR-200 by Novel Approaches Regulates the Expression of PTEN and MT1-MMP in Pancreatic Cancer. Carcinogenesis 33 (8), 1563-1571. doi:10.1093/carcin/bgs189

Steeg, P. S. (2006). Tumor Metastasis: Mechanistic Insights and Clinical Challenges. Nat. Med. 12 (8), 895-904. doi:10.1038/nm1469

Storka, A., Vcelar, B., Klickovic, U., Gouya, G., Weisshaar, S., Aschauer, S., et al. (2015). Safety, Tolerability and Pharmacokinetics of Liposomal Curcumin in Healthy Humans. Cp 53 (1), 54-65. doi:10.5414/cp202076

Su, C. C., Chen, G. W., Lin, J. G., Wu, L. T., and Chung, J. G. (2006). Curcumin Inhibits Cell Migration of Human colon Cancer colo 205 Cells through the Inhibition of Nuclear Factor Kappa B/p65 and Down-Regulates Cyclooxygenase-2 and Matrix Metalloproteinase-2 Expressions. Anticancer Res. 26 (2a), 1281-1288.

Subramani, R., Lopez-Valdez, R., Arumugam, A., Nandy, S., Boopalan, T., Lakshmanaswamy, R., et al. (2014). Targeting Insulin-like Growth Factor 1 Receptor Inhibits Pancreatic Cancer Growth and Metastasis. PLoS One 9 (5), e97016. doi:10.1371/journal.pone.0097016

Sun, X.-D., Liu, X.-E., and Huang, D.-S. (2012). Curcumin Induces Apoptosis of Triple-Negative Breast Cancer Cells by Inhibition of EGFR Expression. Mol. Med. Rep. 6 (6), 1267-1270. doi:10.3892/mmr.2012.1103

Sun, X.-D., Liu, X.-E., and Huang, D.-S. (2013). Curcumin Reverses the EpithelialMesenchymal Transition of Pancreatic Cancer Cells by Inhibiting the Hedgehog Signaling Pathway. Oncol. Rep. 29 (6), 2401-2407. doi:10.3892/ or.2013.2385

Sun, X., Mao, Y., Wang, J., Zu, L., Hao, M., Cheng, G., et al. (2014). IL-6 Secreted by Cancer-Associated Fibroblasts Induces Tamoxifen Resistance in Luminal Breast Cancer. Oncogene 33 (35), 4450. doi:10.1038/onc.2014.158

Swarnakar, S., Ganguly, K., Kundu, P., Banerjee, A., Maity, P., and Sharma, A. V. (2005). Curcumin Regulates Expression and Activity of Matrix Metalloproteinases 9 and 2 during Prevention and Healing of Indomethacin-Induced Gastric Ulcer. J. Biol. Chem. 280 (10), 9409-9415. doi:10.1074/jbc.m413398200

Tabassum, D. P., and Polyak, K. (2015). Tumorigenesis: it Takes a Village. Nat. Rev. Cancer 15 (8), 473-483. doi:10.1038/nrc3971

Takebe, N., Miele, L., Harris, P. J., Jeong, W., Bando, H., Kahn, M., et al. (2015). Targeting Notch, Hedgehog, and Wnt Pathways in Cancer Stem Cells: Clinical Update. Nat. Rev. Clin. Oncol. 12 (8), 445-464. doi:10.1038/nrclinonc.2015.61

Tawada, M., Hayashi, S.-i., Osada, S., Nakashima, S., and Yoshida, K. (2012). Human Gastric Cancer Organizes Neighboring Lymphatic Vessels via Recruitment of Bone Marrow-Derived Lymphatic Endothelial Progenitor Cells. J. Gastroenterol. 47 (9), 1057-1060. doi:10.1007/s00535-012-0638-4

Thiery, J. P. (2002). Epithelial-mesenchymal Transitions in Tumour Progression. Nat. Rev. Cancer 2 (6), 442-454. doi:10.1038/nrc822

Toden, S., Okugawa, Y., Jascur, T., Wodarz, D., Komarova, N. L., Buhrmann, C., et al. (2015). Curcumin Mediates Chemosensitization to 5-fluorouracil through miRNAInduced Suppression of Epithelial-To-Mesenchymal Transition in Chemoresistant Colorectal Cancer. Carcin 36 (3), 355-367. doi:10.1093/carcin/bgv006

Tong, W., Wang, Q., Sun, D., and Suo, J. (2016). Curcumin Suppresses colon Cancer Cell Invasion via AMPK-Induced Inhibition of NF-Kb, uPA Activator and MMP9. Oncol. Lett. 12 (5), 4139-4146. doi:10.3892/ol.2016.5148
Tseng, R.-C., Lee, S.-H., Hsu, H.-S., Chen, B.-H., Tsai, W.-C., Tzao, C., et al. (2010). SLIT2 Attenuation during Lung Cancer Progression Deregulates $\beta$-Catenin and E-Cadherin and Associates with Poor Prognosis. Cancer Res. 70 (2), 543-551. doi:10.1158/0008-5472.can-09-2084

van Buul, J. D., Voermans, C., van Gelderen, J., Anthony, E. C., van der Schoot, C. E., and Hordijk, P. L. (2003). Leukocyte-endothelium Interaction Promotes SDF-1-dependent Polarization of CXCR4. J. Biol. Chem. 278 (32), 30302-30310. doi:10.1074/jbc.m304764200

Vandercappellen, J., Van Damme, J., and Struyf, S. (2008). The Role of CXC Chemokines and Their Receptors in Cancer. Cancer Lett. 267 (2), 226-244. doi:10.1016/j.canlet.2008.04.050

Veeraraghavan, J., Natarajan, M., Lagisetty, P., Awasthi, V., Herman, T. S., and Aravindan, N. (2011). Impact of Curcumin, Raspberry Extract, and Neem Leaf Extract on Rel Protein-Regulated Cell Death/radiosensitization in Pancreatic Cancer Cells. Pancreas 40 (7), 1107-1119. doi:10.1097/mpa.0b013e31821f677d

Vincenti, M. P. (2001). The Matrix Metalloproteinase (MMP) and Tissue Inhibitor of Metalloproteinase (TIMP) Genes. Transcriptional and Posttranscriptional Regulation, Signal Transduction and Cell-type-specific Expression. Methods Mol. Biol. 151, 121-148. doi:10.1385/1-59259-046-2:121

Vincenti, M. P., Coon, C. I., and Brinckerhoff, C. E. (1998). Nuclear Factor ?B/p50 Activates an Element in the Distal Matrix Metalloproteinase 1 Promoter in Interleukin-1?-Stimulated Synovial Fibroblasts. Arthritis Rheum. 41 (11), 1987-1994. doi:10.1002/1529-0131(199811)41:11<1987::aid-art14>3.0.co;2-8

Wang, L.-H., Wu, C.-F., Rajasekaran, N., and Shin, Y. K. (2018). Loss of Tumor Suppressor Gene Function in Human Cancer: An Overview. Cel Physiol Biochem 51 (6), 2647-2693. doi:10.1159/000495956

Wang, Q., Qu, C., Xie, F., Chen, L., Liu, L., Liang, X., et al. (2017). Curcumin Suppresses Epithelial-To-Mesenchymal Transition and Metastasis of Pancreatic Cancer Cells by Inhibiting Cancer-Associated Fibroblasts. Am. J. Cancer Res. 7 (1), 125-133.

Wang, W. X., Sun, S. Z., Guo, X. L., and Song, Y. (2008). Effect of Curcumin on Invasion and Migration of Tongue Squamous Cell Carcinoma Cell Line Tca8113. Zhonghua Kou Qiang Yi Xue Za Zhi 43 (2), 101-104.

Wang, X., Wang, Q., Ives, K. L., and Evers, B. M. (2006). Curcumin Inhibits Neurotensin-Mediated Interleukin-8 Production and Migration of HCT116 Human colon Cancer Cells. Clin. Cancer Res. 12 (18), 5346-5355. doi:10.1158/ 1078-0432.ccr-06-0968

Wang, Y.-J., Pan, M.-H., Cheng, A.-L., Lin, L.-I., Ho, Y.-S., Hsieh, C.-Y., et al. (1997). Stability of Curcumin in Buffer Solutions and Characterization of its Degradation Products. J. Pharm. Biomed. Anal. 15 (12), 1867-1876. doi:10.1016/s0731-7085(96)02024-9

Westermarck, J., and Kähäri, V. M. (1999). Regulation of Matrix Metalloproteinase Expression in Tumor Invasion. FASEB j. 13 (8), 781-792. doi:10.1096/fasebj.13.8.781

Wong, K. E., et al. (2019). Curcumin Nanoformulations for Colorectal Cancer: A Review. Front. Pharmacol. 10, 152. doi:10.3389/fphar.2019.00152

Woo, M.-S., Jung, S.-H., Kim, S.-Y., Hyun, J.-W., Ko, K.-H., Kim, W.-K., et al. (2005). Curcumin Suppresses Phorbol Ester-Induced Matrix Metalloproteinase-9 Expression by Inhibiting the PKC to MAPK Signaling Pathways in Human Astroglioma Cells. Biochem. Biophysical Res. Commun. 335 (4), 1017-1025. doi:10.1016/j.bbrc.2005.07.174

Wu, W.-S., Wu, J.-R., and Hu, C.-T. (2008). Signal Cross Talks for Sustained MAPK Activation and Cell Migration: the Potential Role of Reactive Oxygen Species. Cancer Metastasis Rev. 27 (2), 303-314. doi:10.1007/s10555-008-9112-4

Wysoczynski, M., Reca, R., Ratajczak, J., Kucia, M., Shirvaikar, N., Honczarenko, M., et al. (2005). Incorporation of CXCR4 into Membrane Lipid Rafts Primes Homing-Related Responses of Hematopoietic Stem/progenitor Cells to an SDF1 Gradient. Blood 105 (1), 40-48. doi:10.1182/blood-2004-04-1430

Xia, P., Song, C.-L., Liu, J.-F., Wang, D., and Xu, X.-Y. (2015). Prognostic Value of Circulating CD133+cells in Patients with Gastric Cancer. Cell Prolif. 48 (3), 311-317. doi:10.1111/cpr.12175

Yang, J., Mani, S. A., Donaher, J. L., Ramaswamy, S., Itzykson, R. A., Come, C., et al. (2004). Twist, a Master Regulator of Morphogenesis, Plays an Essential Role in Tumor Metastasis. Cell 117 (7), 927-939. doi:10.1016/j.cell.2004.06.006

Yang, M.-H., Wu, M.-Z., Chiou, S.-H., Chen, P.-M., Chang, S.-Y., Liu, C.-J., et al. (2008). Direct Regulation of TWIST by HIF-1a Promotes Metastasis. Nat. Cel Biol 10 (3), 295-305. doi:10.1038/ncb1691

Yarden, Y., and Sliwkowski, M. X. (2001). Untangling the ErbB Signalling Network. Nat. Rev. Mol. Cel Biol 2 (2), 127-137. doi:10.1038/35052073 
Ye, X., and Weinberg, R. A. (2015). Epithelial-Mesenchymal Plasticity: A Central Regulator of Cancer Progression. Trends Cel Biol. 25 (11), 675-686. doi:10.1016/j.tcb.2015.07.012

Yodkeeree, S., Garbisa, S., and Limtrakul, P. (2008). Tetrahydrocurcumin Inhibits HT1080 Cell Migration and Invasion via Downregulation of MMPs and uPA1. Acta Pharmacol. Sin 29 (7), 853-860. doi:10.1111/j.1745-7254.2008.00792.x

Youns, M., and Fathy, G. M. (2013). Upregulation of Extrinsic Apoptotic Pathway in Curcumin-Mediated Antiproliferative Effect on Human Pancreatic Carcinogenesis. J. Cel. Biochem. 114 (12), 2654-2665. doi:10.1002/jcb.24612

Yoysungnoen, P., Wirachwong, P., Bhattarakosol, P., Niimi, H., and Patumraj, S. (2006). Effects of Curcumin on Tumor Angiogenesis and Biomarkers, COX-2 and VEGF, in Hepatocellular Carcinoma Cell-Implanted Nude Mice. Clin. Hemorheol. Microcirc. 34 (1-2), 109-115.

Yue, G. G.-L., Kwok, H.-F., Lee, J. K.-M., Jiang, L., Wong, E. C.-W., Gao, S., et al. (2016). Combined Therapy Using Bevacizumab and Turmeric Ethanolic Extract (With Absorbable Curcumin) Exhibited Beneficial Efficacy in colon Cancer Mice. Pharmacol. Res. 111, 43-57. doi:10.1016/j.phrs.2016.05.025

Yue, G. G. L., Cheng, S.-W., Yu, H., Xu, Z.-S., Lee, J. K. M., Hon, P.-M., et al. (2012). The Role of Turmerones on Curcumin Transportation and P-Glycoprotein Activities in Intestinal Caco-2 Cells. J. Med. Food 15 (3), 242-252. doi:10.1089/jmf.2011.1845

Yuen, H.-F., Chua, C.-W., Chan, Y.-P., Wong, Y.-C., Wang, X., and Chan, K.-W. (2007). Significance of TWIST and E-Cadherin Expression in the Metastatic Progression of Prostatic Cancer. Histopathology 50 (5), 648-658. doi:10.1111/ j.1365-2559.2007.02665.x

Zajchowski, L. D., and Robbins, S. M. (2002). Lipid Rafts and Little Caves. Eur. J. Biochem. 269 (3), 737-752. doi:10.1046/j.0014-2956.2001.02715.x

Zhang, W., Cui, T., Liu, L., Wu, Q., Sun, L., Li, L., et al. (2015). Improving Antitumor Activity of Curcumin by Polymeric Micelles in Thermosensitive Hydrogel System in Colorectal Peritoneal Carcinomatosis Model. J. Biomed. Nanotechnol 11 (7), 1173-1182. doi:10.1166/jbn.2015.2073

Zhang, Z., Chen, H., Xu, C., Song, L., Huang, L., Lai, Y., et al. (2016). Curcumin Inhibits Tumor Epithelial-Mesenchymal Transition by Downregulating the Wnt Signaling Pathway and Upregulating NKD2 Expression in colon Cancer Cells. Oncol. Rep. 35 (5), 2615-2623. doi:10.3892/or.2016.4669

Zhen, L., Fan, D., Yi, X., Cao, X., Chen, D., and Wang, L. (2014). Curcumin Inhibits Oral Squamous Cell Carcinoma Proliferation and Invasion via EGFR Signaling Pathways. Int. J. Clin. Exp. Pathol. 7 (10), 6438-6446.
Zheng, Z. H., He-yi, Y., Yu-jie, F., and Zhong-tao, Z. (2020). LncRNA KCNQ1OT1 Is a Key Factor in the Reversal Effect of Curcumin on Cisplatin Resistance in the Colorectal Cancer Cells. Mol Cell Biochem. 476 (7), 2575-2585. Springer.

Zhou, Y.-N., et al. (2002). Expression of E-Cadherin and $\beta$-catenin in Gastric Carcinoma and its Correlation with the Clinicopathological Features and Patient Survival. Wjg 8 (6), 987-993. doi:10.3748/wjg.v8.i6.987

Zhu, G. H., Dai, H. P., Shen, Q., Ji, O., Zhang, Q., and Zhai, Y. L. (2016). Curcumin Induces Apoptosis and Suppresses Invasion through MAPK and MMP Signaling in Human Monocytic Leukemia SHI-1 Cells. Pharm. Biol. 54 (8), 1303-1311. doi:10.3109/13880209.2015.1060508

Zhu, L., Zhang, W., Wang, J., and Liu, R. (2015). Evidence of CD90+CXCR4+ Cells as Circulating Tumor Stem Cells in Hepatocellular Carcinoma. Tumor Biol. 36 (7), 5353-5360. doi:10.1007/s13277-015-3196-6

Zhuge, Y., and Xu, J. (2001). Racl Mediates Type I Collagen-dependent MMP-2 Activation. J. Biol. Chem. 276 (19), 16248-16256. doi:10.1074/jbc.m010190200

Conflict of Interest: Author MF was employed by company Giamed Corp.

The remaining authors declare that the research was conducted in the absence of any commercial or financial relationships that could be construed as a potential conflict of interest.

Publisher's Note: All claims expressed in this article are solely those of the authors and do not necessarily represent those of their affiliated organizations, or those of the publisher, the editors and the reviewers. Any product that may be evaluated in this article, or claim that may be made by its manufacturer, is not guaranteed or endorsed by the publisher.

Copyright (c) 2021 Davoodvandi, Farshadi, Zare, Akhlagh, Alipour Nosrani, Mahjoubin-Tehran, Kangari, Sharafi, Khan, Aschner, Baniebrahimi and Mirzaei. This is an open-access article distributed under the terms of the Creative Commons Attribution License (CC BY). The use, distribution or reproduction in other forums is permitted, provided the original author(s) and the copyright owner(s) are credited and that the original publication in this journal is cited, in accordance with accepted academic practice. No use, distribution or reproduction is permitted which does not comply with these terms. 